\title{
The political economy of seigniorage ${ }^{\text {th }}$
}

\author{
Ari Aisen ${ }^{a}$, Francisco José Veiga ${ }^{b, *}$ \\ a International Monetary Fund, 700 19th Street NW, Washington, DC 20431, USA \\ ${ }^{\mathrm{b}}$ Universidade do Minho and NIPE, Escola de Economia e Gestão, P-4710-057 Braga, Portugal
}

Received 5 July 2006; received in revised form 14 December 2007; accepted 18 December 2007

\begin{abstract}
While most economists agree that seigniorage is one way governments finance deficits, there is less agreement about the political, institutional and economic reasons for relying on it. This paper investigates the main political and institutional determinants of seigniorage using panel data on about 100 countries, for the period 1960-1999. Estimates show that greater political instability leads to higher seigniorage, especially in developing, less democratic and socially-polarized countries, with high inflation, low access to domestic and external debt financing and with higher turnover of central bank presidents. One important policy implication of this study is the need to develop institutions conducive to greater political stability as a means to reduce the reliance on seigniorage financing of public deficits.
\end{abstract}

(C) 2008 Elsevier B.V. All rights reserved.

JEL classification: E31; E63

Keywords: Seigniorage; Political instability; Institutions

\section{Introduction}

The purpose of this paper is to identify the main determinants of cross-country and cross-time differ-

\footnotetext{
is The authors acknowledge the helpful comments from Christopher Bowdler, Juan Jauregui, Delfim Neto, Carlos Végh, Robert Flood, Paolo Mauro, various staff members from the International Monetary Fund, two anonymous referees, and the editor, Lant Pritchett. We also thank Reid Click for sharing his data on creditworthiness ratings. The views expressed in this paper are those of the authors and do not necessarily represent those of the IMF or IMF policy. Francisco Veiga wishes to thank the Portuguese Foundation for Science and Technology (FCT) for research grant POCI/EGE/55423/2004 (partially funded by FEDER).

* Corresponding author. Universidade do Minho, Escola de Economia e Gestão, P-4710-057 Braga, Portugal. Tel.: +351 253604534; fax: +351 253676375.

E-mail addresses: aaisen@imf.org (A. Aisen), fjveiga@eeg.uminho.pt (F.J. Veiga).
}

ences in seigniorage - real revenues a government acquires by using newly issued money to buy goods and non-money assets. ${ }^{1}$ This is a challenge not yet satisfactorily confronted by the economics profession for four reasons. First, several political and institutional variables used as explanatory variables in earlier studies were relatively poorer measures of political instability and of the institutional environment than those available in new datasets such as the Cross National Time Series

\footnotetext{
${ }^{1}$ Some studies, such as Buiter (2007), distinguish seigniorage (change in monetary base) from central bank revenue (interest earned by investing the resources obtained through the past issuance of base money). This distinction is useful to study central bank operations and monetary policy effectiveness. For the purposes of this paper, however, it suffices to broadly define seigniorage as revenues obtained by a consolidated government (treasury and central bank) from the issuance of base money.
} 
Data Archive (CNTS), Database of Political Institutions (DPI), the Polity IV Database, State Failure Task Force (SFTF) database, and the Freedom House ratings. Second, our analysis is based on a richer and wider dataset, covering more countries and years than those used in previous studies, and includes a larger variety of alternative model specifications. Third, although Aisen and Veiga (2006) study the determinants of inflation using a similar dataset, one should not expect that variables affecting inflation should affect seigniorage in the exact same way, since the latter might be consistent with two different levels of the former in the presence of a well-defined Laffer curve. According to Easterly et al. (1995), studying inflation is different to studying seigniorage, especially for developing and high-inflation countries. Accordingly, the correlation between inflation and seigniorage in our sample fluctuates significantly depending on the rate of inflation (see Table 1). While it is positive most of the time and for most of the countries, it declines with the level of inflation and becomes negative for inflation rates above $400 \%$ per year. Thus, it is misleading to assume that the determinants of inflation are necessary the same as those of seigniorage, which means that separate studies of these variables should be made. As an example, changes in inflation may result from supply-side shocks, such as fluctuations in oil prices, which do not directly affect seigniorage. Conversely, the structure of the economy, which affects the capacity to raise taxes and the reliance on seigniorage revenues, may not affect inflation in the same way. Fourth, our models are able to identify the circumstances under which the relationship between political instability and seigniorage is stronger, a central topic of our research and virtually absent from previous empirical studies on the determinants of seigniorage. While seigniorage seems to be a less attractive method of government financing for several countries, the truth

Table 1

Correlation between inflation and seigniorage

\begin{tabular}{lcc}
\hline Sample & Observations & Correlation \\
\hline All & 3171 & .214 \\
Inflation $<10 \%$ & 1967 & .102 \\
Inflation $<100 \%$ & 3083 & .305 \\
Inflation $>100 \%$ & 88 & .132 \\
Inflation $>200 \%$ & 43 & .058 \\
Inflation $>300 \%$ & 34 & .0001 \\
Inflation $>400 \%$ & 28 & -.007 \\
Inflation $>500 \%$ & 26 & -.038 \\
Inflation $>1000 \%$ & 18 & -.139 \\
\hline
\end{tabular}

Notes: inflation is the annual inflation rate (IFS line $64 \times$ ). Seigniorage is the change in reserve money (IFS, line 14a) as a percentage of government revenues (IFS line 81). is that it was still used to a greater extent in the $1990 \mathrm{~s}$ than in the 1960s. Furthermore, seigniorage revenues are on average five times higher in developing countries than in industrial countries for the period 1960-1999. In the $1990 \mathrm{~s}$, average seigniorage revenues represented $14.65 \%$ of total government revenues for developing countries, compared to only $1.64 \%$ for industrial countries. Therefore, analyzing the determinants of seigniorage is an important endeavor, primarily for developing countries.

Relying upon the theoretical literature and using a dataset covering around 100 countries for the period 1960-1999, we estimate panel data models to investigate the main economic, political and institutional determinants of seigniorage. After controlling for the countries' economic structure and for several other variables that may affect seigniorage, we find that greater political instability leads to higher seigniorage levels, confirming previous results by Cukierman et al. (1992) and Click (1998).

This paper's major contribution to the literature is the identification of the circumstances under which the above-referred relationship is stronger. That is, we find that political instability has stronger effects on seigniorage levels in higher inflation than in moderate and low inflation countries, and also in developing than in industrial nations. In addition, this relationship is also stronger in countries with (i) higher social polarization; (ii) a tradition of high political instability; ${ }^{2}$ (iii) higher central bank president turnover (lower de facto central bank independence); (iv) lower indexes of economic freedom; (v) more authoritarian regimes; (vi) higher domestic debt levels as a percentage of GDP; (vii) lower access to international financing (expressed in poorer creditworthiness ratings); and, (viii) lower openness to international trade. It is also worth mentioning that, besides its effects on the relationship between political instability and seigniorage, social polarization is by itself a major determinant of seigniorage. Empirical results show quite clearly that higher degrees of social polarization (lower ethnic homogeneity) are associated with higher levels of seigniorage.

The paper is structured as follows. A survey of the empirical and theoretical literature on the relationship between seigniorage, political instability and institutions is presented in Section 2. The dataset and the empirical models are described in Section 3. Section 4 presents the empirical results, and Section 5 concludes the paper.

\footnotetext{
${ }^{2}$ Expressed in a high number of state failure events in the last 15 years, such as revolutionary wars, ethnic wars, regime crises, and genocides/politicides.
} 


\section{The political economy of seigniorage}

Most economists acknowledge that differences on the way countries conduct their fiscal policies are behind the variability of the seigniorage levels they sustain. ${ }^{3}$ But this explanation leads to a much deeper and fundamental question, which is why countries differ on the way they conduct fiscal policies (see Woo, 2003, 2005). In particular, governments that are able to finance their expenditures through taxes or debt do not need to rely on seigniorage revenues. Several studies have explored the idea that structural features of a particular economy help determine its "taxable capacity". Chelliah et al. (1975), for example, provide evidence that countries with larger per capita non-export income, more open to trade and with larger mining but smaller agricultural sectors have, on average, a higher "taxable capacity" or ease of collection. This result leads to the conclusion that the countries' ability to tax is technologically constrained by their stage of development and by the structure of their economies (e.g. size of the agricultural sector in GDP), and as tax collecting costs are high and tax evasion pervasive, countries might use seigniorage more frequently. But what if governments, independently of their countries' economic structures, find it optimal to finance expenditures using seigniorage rather than levying other taxes (e.g. taxes on output)? The Theory of Optimal Taxation (see Phelps, 1973; Végh, 1989; Aizenman, 1992) rationalizes government behavior in many countries showing that it might be optimal for governments to rely on seigniorage if other taxes are highly distortionary. According to this theory, governments optimally equate the marginal cost of the inflation tax with that of output taxes, therefore minimizing the distortions to the economy when choosing the optimal combination of taxes to finance their expenditures. Edwards and Tabellini (1991) and Cukierman et al. (1992) fail to find evidence that this theory applies to developing countries. Click (1998) estimates a model using 90 countries, from 1971-90, and finds that only $40 \%$ of the cross-country variation in seigniorage can be explained with the Theory of Optimal Taxation. The empirical failure of this theory to fully explain the cross-country differences in the use of seigniorage revenues motivated the use of theoretical and empirical models focusing on the role played by political and institutional variables.

\footnotetext{
${ }^{3}$ See Catão and Torrones (2005) for an empirical analysis on the relationship between fiscal deficits and inflation and Fischer et al. (2002) for a survey on modern hyper- and high inflations that includes results showing a positive relationship between fiscal deficits and seigniorage.
}

Cukierman et al. (1992) develop a theoretical model whereby political instability and ideological polarization determine the equilibrium efficiency of the tax system and the resulting combination of tax revenues and seigniorage that governments use. Using a probit model to determine the likelihood of an incumbent government to remain in power, they show evidence that higher political instability and ideological polarization lead to higher seigniorage. In the empirical analysis of Section 4, we employ alternative and more direct measures of political instability, such as variables that count the exact number of cabinet changes, executive changes or government crises taking place in a particular year. Moreover, whereas they use a dummy variable for democratic regimes as a proxy for ideological polarization, we use the Polity Scale (ranged between -10 and +10 ) to measure the degree of democracy in different countries, and an ethnic homogeneity index as a proxy for the degree of social polarization. ${ }^{4}$

In line with Cukierman et al. (1992), we conjecture that economies with weaker institutions might be unable to build efficient tax systems leading them to use more frequently seigniorage as a source of revenue. In the next sections, in addition to the effects of political instability on seigniorage, we also estimate the effects of institutions such as democracy and economic freedom. Besides structural variables accounting for the taxing capacity of the economy and political and institutional variables affecting the use of seigniorage financing of fiscal deficits, we also consider, in line with Click (1998), variables that measure the ability of governments to finance transitory expenditures with domestic or external debt. To the extent that a government is able to finance its expenditure through debt, there is less need to rely on seigniorage.

Our main contribution to the literature is that our models not only identify the main political and economic determinants of seigniorage, but also reveal under which circumstances the effects of political instability on seigniorage are stronger. Our results indicate that the causal effect of political instability on seigniorage is stronger in developing and high-inflation countries. In addition, it is also stronger in socially-polarized, ${ }^{5}$ less

\footnotetext{
${ }^{4}$ An additional shortcoming of the analysis in Cukierman et al. (1992) is the use of a cross-sectional dataset using averages from 1971 to 1982 for only 79 countries, while we use a panel dataset covering around 100 countries for the period 1960-99.

5 See Beetsma and Van Der Ploeg (1996), Bhattacharya et al. (2005) and Albanesi (2007) for studies presenting evidence suggesting that inflation and income inequality are positively related. In Desai et al. (2005) that relationship is conditional on the political structure. Woo (2005) finds that social polarization is associated with fiscal instability while generating incentives to engage in short-term policies leading to lower growth. Our findings indicate that the fiscal instability channel may also lead to higher seigniorage and inflation.
} 
democratic, traditionally unstable, and highly indebted countries. Finally, political instability has greater effects on seigniorage in countries that have lower de facto central bank independence, lower economic freedom, lower creditworthiness ratings and lower openness to international trade. In our view, and to the best of our knowledge, there is no comprehensive study in the literature fully analyzing the relationship between political instability and seigniorage. As it will become clear in the following sections, this paper is an attempt to contribute in this direction.

\section{Data and the empirical model}

The dataset is composed of annual data on political, institutional and economic variables for the years 1960 to 1999. Although we collected data for 178 countries, missing values for several variables reduce the number of countries in our estimations to around 100. The sources of political and institutional data are: the Cross National Time Series Data Archive (CNTS); the Polity IV dataset; ${ }^{6}$ Gwartney and Lawson (2002); ${ }^{7}$ the Database of Political Institutions (DPI 3.0); ${ }^{8}$ the State Failure Task Force dataset (SFTF) $;^{9}$ and the Freedom House ratings. ${ }^{10}$ Economic data was collected from the World Bank's World Development Indicators (WDI) and Global Development Network Growth Database (GDN), ${ }^{11}$ the International Monetary Fund's International Financial Statistics (IFS), the Penn World Tables (PWT 6.1), ${ }^{12}$ Euromoney creditworthiness ratings, ${ }^{13}$ Cukierman et al. (1995), ${ }^{14}$ Dollar and Kraay (2002), ${ }^{15}$ and Levy-Yeyati and Sturzenegger (2003). ${ }^{16}$

\footnotetext{
${ }^{6}$ Available on the Internet (http://www.cidcm.umd.edu/inscr/polity/ index.htm).

${ }^{7}$ Available on the Internet (http://www.freetheworld.com/release.html).

${ }^{8}$ On this database, see Beck et al. (2001). Available on the Internet though Philip Keefer's page in the World Bank's site (http://www. worldbank.org/research/bios/pkeefer.htm).

9 Available on the Internet (http://www.cidcm.umd.edu/inscr/stfail/ sfdata.htm)

${ }^{10}$ Available on the Internet (http://www.freedomhouse.org/ratings/).

11 Available on the Internet (http://www.worldbank.org/research/ growth/GDNdata.htm).

12 Available on the Internet (http://pwt.econ.upenn.edu/php_site/ pwt_index.php).

13 The data on the Euromoney creditworthiness index, raging from 0 to 100 , from 1982 to 1999 , was kindly provided by Reid Click.

${ }^{14}$ Underlying data available on the Internet (http://www.tau.ac.il/ $\sim$ alexcuk/pdf/WebbPoltime2.xls).

${ }^{15}$ Underlying data available on the Internet (http://siteresources. worldbank.org/INTRES/Resources/469232-1107449512766/648083$1108140788422 /$ Growth_is_good_for_the_poor_data.zip).

${ }^{16}$ Underlying data available on the Internet (http://www.utdt.edu/ $\sim$ fsturzen/base_2002.xls).
}

To investigate the main political, institutional and economic determinants of seigniorage levels across countries and time, we estimate panel data models, controlling for countries' fixed effects. Seigniorage is defined in two alternative ways: (1) the change in reserve money (line 14a of IFS-IMF) as a percentage of nominal GDP (line 99b in IFS-IMF); (2) the change in reserve money (line 14a of IFS-IMF) as a percentage of government revenues (line 81 in IFS-IMF). Appendix A shows the number of observations, means and standard deviations of these seigniorage measures for all countries for which data is available. ${ }^{17}$

We hypothesize that seigniorage levels depend on the following explanatory variables:

- A set of variables representing political instability, polarization and institutions:

o Cabinet Changes (CNTS), a proxy for political instability, counts the number of times in a year in which a new premier is named and/or $50 \%$ of the cabinet posts are occupied by new ministers. A positive coefficient is expected, as greater instability should lead to greater reliance on seigniorage revenues.

Why may the number of cabinet changes be a good indicator of political instability? First, in a country characterized by frequent changes in the composition of government, there are also frequent changes in macroeconomic policies, as new prime ministers or ministers of finance/economics do not necessarily share the views of their predecessors. Second, frequent cabinet changes shorten the horizon of the members of government, as they are not certain that they will keep their posts during an entire term. The higher the probability of being replaced, the greater will be the importance attributed to shortterm objectives. Then, since the costs of future inflation are not fully internalized, it is difficult to resist the temptation to finance current expenditures with seigniorage revenues.

\footnotetext{
17 There is data on $\triangle R M / G D P$ for 144 countries and on $\triangle R M / G R$ for 122 countries. These are the seigniorage measures most commonly used in the literature. We performed all estimations for both measures but, to make our results more easily comparable to those of Cukierman et al. (1992), we report in most tables those obtained when using the change in reserve money as a percentage of government revenues. Two additional ways of measuring seigniorage, used by Cukierman et al. (1992), are the product of reserve money by the inflation rate divided by either GDP or government revenues. These authors have shown that these two additional alternative measures of seigniorage provide similar results for a cross-section of countries. Another alternative, used by Click (1998), is the change in the monetary base as a percentage of government spending.
} 
o Ethnic Homogeneity Index (SFTF): ranges from 0 to 1 , with higher values indicating ethnic homogeneity, and equals the sum of the squared population fractions of the seven largest ethnic groups in a country. For each year, it takes the value of the index in the beginning of the respective decade. According to Woo $(2003,2005)$ higher social polarization, which can be proxied by ethnic heterogeneity, leads to higher polarization of preferences for different types of government spending and to public deficits. Thus, a negative coefficient is expected;

o Polity Scale (Polity IV): from strongly autocratic $(-10)$ to strongly democratic (10). Although the economic theory is not conclusive, we anticipate that democracy is associated with lower reliance on seigniorage (negative coefficient); ${ }^{18}$

- A set of economic structural variables that reflect characteristics of the countries that may affect their capacity to control inflation:

o Agriculture (\%GDP): share of the value added of agriculture in GDP (WDI, WB). According to Chelliah et al. (1975), a positive coefficient is expected. An alternative proxy for the structure of the economy is Urban Population (\% of total), the urbanization ratio (WDI, WB), which according to Edwards and Tabellini (1991) should have a negative sign;

o Trade (\%GDP): openness to trade (WDI, WB). Since it is associated with larger revenues of import duties, we expect that countries more open to trade rely less on seigniorage revenues (a negative coefficient is expected); ${ }^{19}$

o Real GDP per capita (PWT 6.1). Richer countries have more efficient tax systems and, thus, have a lesser need for seigniorage (negative coefficient expected);

- Variables accounting for economic performance and external shocks:

o \% Change in Terms of Trade (WDI, WB). Favorable evolution of terms of trade provides greater tax revenues (negative coefficient expected);

o Growth of real GDP(WDI, WB). Higher growth rates are associated with increasing tax revenues, reducing the need for seigniorage (negative coefficient);

\footnotetext{
${ }^{18}$ Although ethnic homogeneity and the polity scale may also be related with political instability, we see them more as institutional variables than as indicators of political instability.

19 The outcome on seigniorage may be similar, even if more open countries are imposing lower tariffs. These countries may rely less on seigniorage in order to avoid the real appreciation of the home currency associated with higher inflation. We owe this rationale to an anonymous referee.
}

- Variables accounting for fixed effects of countries and time:

o Country dummy variables;

o Dummy variables for each decade: 1960s, 1970s, 1980s and 1990s.

Appendix B presents the descriptive statistics for the above-described dependent and independent variables and for additional/alternative explanatory variables that appear in the tables shown in the paper.

The empirical model for seigniorage levels can be summarized as follows:

$$
\begin{aligned}
S_{i t}= & \alpha \mathrm{PI}_{i, t-1}+\beta \mathrm{SP}_{i t}+\delta \mathrm{PS}_{i t}+\mathbf{E c o}_{i t}^{\prime} \boldsymbol{\varphi}+\mathbf{E c P}_{i t}^{\prime} \boldsymbol{\gamma} \\
& +v_{i}+\varepsilon_{i t}, \quad i=1, \ldots, N \quad t=1, \ldots, T_{i}
\end{aligned}
$$

where $S$ is seigniorage, PI is a proxy for political instability, SP is a proxy for social polarization, PS is the Polity Scale, Eco is a vector of economic structural variables, EcP is a vector of variables accounting for economic performance and external shocks, $v_{i}$ is the fixed effect of country $i$, and $\varepsilon_{i t}$ is the error term.

It is worth noting that seigniorage is not persistent (its first lag is never statistically significant when included as an explanatory variable) and that the error term of Eq. (1), $\varepsilon_{i t}$, is not serially correlated. Fisher type unit root tests for panel data reject the null hypothesis that seigniorage is non-stationary in all countries. ${ }^{20}$ DickeyFuller and Augmented Dickey-Fuller tests performed on each individual country reject unit root behavior of seigniorage for all countries that have at least ten observations (in 15 countries, a drift term has to be included). These results, which are available upon request, are consistent with those of Click (2000), who rejected a unit root behavior of seigniorage in the four countries considered in his study (USA, UK, Brazil, and Argentina).

The proxy for political instability $\left(P I_{i, t-1}\right)$ is lagged one period for two reasons. First, political instability may translate into higher seigniorage only after some time. Furthermore, if a cabinet change occurs in the end of one year, it is very likely to lead to higher seigniorage

${ }^{20}$ The results of three of those tests are presented below:

Fisher Test (0 lags, no drift). Ho: unit root

$$
\operatorname{chi}^{2}(244)=1964.3487 \quad \text { Prob }>\operatorname{chi}^{2}=0.0000
$$

Fisher Test (1 lag, no drift). Ho: unit root

$$
\operatorname{chi}^{2}(240)=1360.5939 \quad \text { Prob }>\operatorname{chi}^{2}=0.0000
$$

Fisher Test (0 lags, with a drift term). Ho: unit root

$$
\operatorname{chi}^{2}(240)=2095.2873 \quad \text { Prob }>\operatorname{chi}^{2}=0.0000 .
$$


only in the following year. Second, since from Aisen and Veiga (2006) higher seigniorage leads to higher inflation, which may affect political instability, using the contemporaneous value of political instability could create simultaneity/endogeneity problems. Taking the first lag avoids these problems, as current seigniorage does not affect past political instability. Since current seigniorage can affect current economic growth, Growth of $G D P$ is also lagged one period. ${ }^{21}$

\section{Empirical results}

The first objective of our empirical analysis is to identify the main political, institutional and economic determinants of seigniorage levels across countries and time. Then, after finding strong support for our hypothesis that greater political instability leads to higher seigniorage, we try to determine under which circumstances or country characteristics this relationship is stronger. Finally, we perform a sensitivity analysis that checks whether or not the main results hold for alternative proxies of political instability, for an alternative definition of seigniorage, for a sample that only includes developing countries, when our main proxy for political instability (Cabinet Changes) is defined in a different way, for a cross-section and for samples of 5-year and 10-year periods, when outliers are controlled for, and when instrumental variables are used to account for the possibility that some explanatory variables are endogenous.

\subsection{Main determinants of seigniorage levels}

The estimation results of the model described in the previous section, using a fixed effects specification, ${ }^{22}$ are shown in Table 2. The dependent variable is the change in reserve money as a percentage of government revenues, and all explanatory variables described in the previous section were included in the estimation reported in column 1. Results confirm the hypothesis that greater political instability leads to higher seigniorage levels, and show that the effects are sizeable: an additional cabinet change increases seigniorage as a percentage of government revenues by 4.15 percentage points. Higher values of the Ethnic Homogeneity Index (lower social polarization)

\footnotetext{
21 The contemporaneous values are used for the remaining explanatory variables, since they are taken as exogenous.

${ }^{22}$ Hausmann tests indicate that the fixed effects specification is preferable to a random effects model, and the joint statistical significance of the country dummies implies that a fixed effects model is preferable to a simple pooled OLS model. These results are available from the authors upon request.
}

are associated with lower use of seigniorage, which is consistent with the findings of Cukierman et al. (1992) ${ }^{23}$ and Woo (2003), and with the theoretical model of Woo (2005). Democracy does not seem to affect seigniorage, as the Polity Scale is not statistically significant. ${ }^{24}$ Regarding the economic variables, only Agriculture (\%GDP), Real GDP per capita, and Growth of Real GDP $(-1)$ are statistically significant, with the expected signs. Finally, the coefficients on the decade dummy variables are all positive and statistically significant.

Since Trade (\%GDP) and \%Change in Terms of Trade are not statistically significant in the first column, they are excluded from the model of column $2 .{ }^{25}$ Results remain practically the same. Then, in column 3, Agriculture $(\% G D P)$ was replaced by an alternative proxy for the structure of the economy, Urban Population (\% of total), for which there is a higher number of observations. The negative coefficient conforms to the idea that greater urbanization ratios are associated with greater ease to collect taxes and, thus, with lower seigniorage (see Edwards and Tabellini, 1991). The only changes in results are that the Ethnic Homogeneity Index becomes highly statistically significant, and the coefficients of the decade dummies indicate that seigniorage increased until the 1980s and slightly decreased in the 1990s. Since this specification of column 3 increases the number of observations by 324 (or 16.3\%) and the number of countries by 7 (or 7\%) relative to that of column 2, it will be used as our reference model.

Results regarding political instability ${ }^{26}$ conform to our expectations and are consistent with those found by Aisen and Veiga (2006) for inflation levels, and with those of Cukierman et al. (1992) using cross-sectional data. Those concerning economic variables are consistent with the findings of previous studies, such as Chelliah et al. (1975), Edwards and Tabellini (1991), and Click (1998), indicating that larger agricultural

\footnotetext{
23 Although Cukierman et al. (1992) refer to ideological polarization, the crucial factor in their model is the polarization of preferences for different types of government spending, which can also result from social polarization. Furthermore, higher social polarization is generally associated with higher ideological polarization.

24 This is not surprising, as Aisen and Veiga (2006) found that democracy marginally affects inflation and the effect is very small.

${ }^{25}$ They are never statistically significant when included in the models of the following columns of Table 2 or in those of the following tables. Wald tests allow for the exclusion of these variables from the model.

26 The results obtained when using three alternative proxies of political instability also available in the Cross National Time Series Data Archive - Government Crises, Executive Changes, and the Weighted Conflict Index - are very similar. These results are not shown here, but are available from the authors upon request.
} 
Table 2

Results for seigniorage

\begin{tabular}{|c|c|c|c|c|}
\hline Seigniorage & 1 & 2 & 3 & 4 \\
\hline Cabinet Changes $(-1)$ & $\begin{array}{l}4.149 \\
(2.52)^{* *}\end{array}$ & $\begin{array}{l}3.688 \\
(2.45)^{* * *}\end{array}$ & $\begin{array}{l}4.282 \\
(3.01)^{* * * *}\end{array}$ & $\begin{array}{l}4.309 \\
(2.99)^{* * *}\end{array}$ \\
\hline Ethnic Homogeneity Index & $\begin{array}{l}-22.776 \\
(-1.78)^{*}\end{array}$ & $\begin{array}{l}-22.419 \\
(-1.86)^{*}\end{array}$ & $\begin{array}{l}-24.054 \\
(-2.65)^{* * *}\end{array}$ & $\begin{array}{l}-24.747 \\
(-2.78)^{* * *}\end{array}$ \\
\hline Polity Scale & $\begin{array}{l}.380 \\
(1.44)\end{array}$ & $\begin{array}{l}.379 \\
(1.55)\end{array}$ & $\begin{array}{l}.300 \\
(1.45)\end{array}$ & $\begin{array}{l}.306 \\
(1.50)\end{array}$ \\
\hline Agriculture (\%GDP) & $\begin{array}{l}1.748 \\
(3.62)^{* * *}\end{array}$ & $\begin{array}{l}1.594 \\
(3.57)^{* * *}\end{array}$ & & \\
\hline Urban population ( $\%$ of total) & & & $\begin{array}{l}-.486 \\
(-2.39)^{* *}\end{array}$ & $\begin{array}{l}-.565 \\
(-2.58)^{* * *}\end{array}$ \\
\hline Trade (\%GDP) & $\begin{array}{l}.013 \\
(.20)\end{array}$ & & & \\
\hline Real GDP per capita & $\begin{array}{l}-.001 \\
(-3.77)^{* * *}\end{array}$ & $\begin{array}{l}-.001 \\
(-4.23)^{* * *}\end{array}$ & $\begin{array}{l}-.002 \\
(-5.32)^{* * *}\end{array}$ & $\begin{array}{l}-.002 \\
(-5.11)^{* * *}\end{array}$ \\
\hline$\%$ Change in terms of trade & $\begin{array}{l}.89 \mathrm{e}^{-07} \\
(1.32)\end{array}$ & & & \\
\hline Growth of real GDP $(-1)$ & $\begin{array}{l}-.467 \\
(-2.97)^{* * *}\end{array}$ & $\begin{array}{l}-.432 \\
(-3.05)^{* * *}\end{array}$ & $\begin{array}{l}-.664 \\
(-3.85)^{* * *}\end{array}$ & $\begin{array}{l}-.655 \\
(-3.87)^{* * *}\end{array}$ \\
\hline Dummy1970s & $\begin{array}{l}10.247 \\
(3.88)^{* * *}\end{array}$ & $\begin{array}{l}8.779 \\
(4.09)^{* * *}\end{array}$ & $\begin{array}{l}7.088 \\
(3.83)^{* * *}\end{array}$ & \\
\hline Dummy1980s & $\begin{array}{l}18.575 \\
(3.97)^{* * *}\end{array}$ & $\begin{array}{l}16.998 \\
(4.17)^{* * *}\end{array}$ & $\begin{array}{l}13.448 \\
(3.85)^{* * *}\end{array}$ & \\
\hline Dummy1990s & $\begin{array}{l}19.476 \\
(3.34)^{* * *}\end{array}$ & $\begin{array}{l}17.651 \\
(3.56)^{* * *}\end{array}$ & $\begin{array}{l}12.367 \\
(2.80)^{* * *}\end{array}$ & \\
\hline Trend & & & & $\begin{array}{l}1.622 \\
(4.67)^{* * *}\end{array}$ \\
\hline Trend $^{2}$ & & & & $\begin{array}{l}-.026 \\
(-4.06)^{* * *}\end{array}$ \\
\hline \# Observations & 1836 & 1982 & 2306 & 2306 \\
\hline \# Countries & 97 & 101 & 108 & 108 \\
\hline Adjusted $R^{2}$ & .25 & .25 & .22 & .22 \\
\hline Adjusted $R^{2}$ (without fixed effects) & & & .07 & .07 \\
\hline
\end{tabular}

Notes: Panel regressions with fixed effects of countries and a constant. T-statistics based on heteroskedastic consistent standard errors are in parenthesis; Significance level at which the null hypothesis is rejected: ***, $1 \%$; **, 5\%, and $*, 10 \%$; Seigniorage, the dependent variable, was defined as the change in reserve money (IFS, line 14a) as a percentage of government revenues (IFS line 81).

sectors, lower urbanization ratios, lower GDP per capita levels, and slower economic growth are associated with greater reliance on seigniorage revenues. ${ }^{27}$

The time-dimension of seigniorage is captured by the decade dummies (column 3) and by a quadratic trend (column 4). These indicate that seigniorage increased until the 1980s, and declined during the nineties. In fact, the estimated coefficients of Trend and Trend ${ }^{2}$ indicate that seigniorage hit its peak in 1990, and declined afterwards. Although one would expect the increased independence of central banks in industrial countries to

\footnotetext{
27 The first three variables were not statistically significant in Aisen and Veiga (2006). That is, those structural variables help explain seigniorage but not inflation, supporting our assertion in the introduction that their determinants are not the same and that separate studies for inflation and seigniorage should be implemented.
}

start reducing seigniorage sooner, several developing countries still had high inflation (or even hyperinflation) and seigniorage in the late 1980s and in the beginning of the $1990 \mathrm{~s} .{ }^{28}$ It is also interesting to note that most explanatory variables, with the exception of Cabinet Changes, exhibit relatively low time-series variation within each country. In fact, while Cabinet Changes has an average coefficient of variation within countries of 1.48 , those of the other explanatory variables are all below .25 (the lowest is .065 for the Ethnic Homogeneity Index, which varies very little over time).

As mentioned above, the country dummy variables are always jointly statistically significant. They account for a considerable part of the adjusted $R^{2}$ of .22 reported

\footnotetext{
${ }^{28}$ For example, Argentina had hyperinflation in 1989, Brazil in 1990 and 1994, Peru in 1990, etc.
} 
Table 3

Additional determinants of seigniorage

\begin{tabular}{|c|c|c|c|c|c|c|c|}
\hline Seigniorage & 1 & 2 & 3 & 4 & 5 & 6 & 7 \\
\hline Cabinet Changes $(-1)$ & $\begin{array}{l}4.638 \\
(2.62)^{* * *}\end{array}$ & $\begin{array}{l}4.372 \\
(3.07)^{* * *}\end{array}$ & $\begin{array}{l}4.299 \\
(3.03)^{* * *}\end{array}$ & $\begin{array}{l}5.686 \\
(2.59)^{* * *}\end{array}$ & $\begin{array}{l}5.965 \\
(2.78)^{* * *}\end{array}$ & $\begin{array}{l}3.150 \\
(2.76)^{* * *}\end{array}$ & $\begin{array}{l}1.253 \\
(1.51)\end{array}$ \\
\hline Ethnic Homogeneity Index & $\begin{array}{l}-56.688 \\
(-3.22)^{* * *}\end{array}$ & $\begin{array}{l}-23.074 \\
(-2.62)^{* * *}\end{array}$ & $\begin{array}{l}-23.869 \\
(-2.68) * * *\end{array}$ & $\begin{array}{l}-86.308 \\
(-1.89)^{*}\end{array}$ & $\begin{array}{l}-74.736 \\
(-3.29)^{* * *}\end{array}$ & $\begin{array}{l}-22.404 \\
(-2.15)^{* *}\end{array}$ & $\begin{array}{l}-6.727 \\
(-.63)\end{array}$ \\
\hline Polity Scale & $\begin{array}{l}.529 \\
(1.74)^{*}\end{array}$ & $\begin{array}{l}.266 \\
(1.35)\end{array}$ & $\begin{array}{l}.313 \\
(1.49)\end{array}$ & $\begin{array}{l}.550 \\
(1.32)\end{array}$ & $\begin{array}{l}.148 \\
(.31)\end{array}$ & $\begin{array}{l}.121 \\
(.49)\end{array}$ & $\begin{array}{l}.178 \\
(1.18)\end{array}$ \\
\hline Urban population ( $\%$ of total) & $\begin{array}{l}-.573 \\
(-2.19)^{* *}\end{array}$ & $\begin{array}{l}-.430 \\
(-2.29)^{* *}\end{array}$ & $\begin{array}{l}-.548 \\
(-2.46)^{* *}\end{array}$ & $\begin{array}{l}-1.144 \\
(-2.52)^{* *}\end{array}$ & $\begin{array}{l}-.654 \\
(-1.64)\end{array}$ & $\begin{array}{l}-.502 \\
(-2.21)^{* *}\end{array}$ & $\begin{array}{l}-.033 \\
(-.22)\end{array}$ \\
\hline Real GDP per capita & & $\begin{array}{l}-.002 \\
(-5.15) * * *\end{array}$ & $\begin{array}{l}-.001 \\
(-5.62)^{* * *}\end{array}$ & $\begin{array}{l}-.001 \\
(-1.13)\end{array}$ & $\begin{array}{l}.001 \\
(1.41)\end{array}$ & $\begin{array}{l}-.001 \\
(-1.94)^{*}\end{array}$ & $\begin{array}{l}-.001 \\
(-4.11)^{* * *}\end{array}$ \\
\hline Growth of real GDP $(-1)$ & $\begin{array}{l}-.568 \\
(-2.89) * * *\end{array}$ & $\begin{array}{l}-.617 \\
(-3.88)^{* * *}\end{array}$ & $\begin{array}{l}-.616 \\
(-3.85)^{* * *}\end{array}$ & $\begin{array}{l}-.701 \\
(-3.03)^{* * *}\end{array}$ & $\begin{array}{l}-.624 \\
(-2.97)^{* * * *}\end{array}$ & $\begin{array}{l}-.510 \\
(-3.43)^{* * *}\end{array}$ & $\begin{array}{l}-.380 \\
(-2.72)^{* * *}\end{array}$ \\
\hline Index of economic freedom & $\begin{array}{l}-9.381 \\
(-5.27)^{* * *}\end{array}$ & & & & & & \\
\hline Revolutionary war & & $\begin{array}{l}12.561 \\
(1.86)^{*}\end{array}$ & & & & & \\
\hline Civil/ethnic conflicts in border states & & & $\begin{array}{l}5.530 \\
(1.99)^{* *}\end{array}$ & & & & \\
\hline Exchange rate regime & & & & $\begin{array}{l}-2.416 \\
(-2.91)^{* * *}\end{array}$ & & & \\
\hline Creditworthiness & & & & & $\begin{array}{l}-.309 \\
(-2.40)^{* *}\end{array}$ & & \\
\hline Deposit money bank assets/central bank assets & & & & & & $\begin{array}{l}-32.155 \\
(-1.95)^{*}\end{array}$ & \\
\hline Liquid liabilities (\%GDP) & & & & & & & $\begin{array}{l}-3.325 \\
(-.41)\end{array}$ \\
\hline \# Observations & 1758 & 2295 & 2293 & 1433 & 1168 & 2182 & 1688 \\
\hline \# Countries & 93 & 108 & 108 & 101 & 106 & 107 & 94 \\
\hline Adjusted $R^{2}$ & .24 & .22 & .22 & .20 & .34 & .25 & .25 \\
\hline
\end{tabular}

Notes: Panel regressions with country fixed effects. $T$-statistics based on heteroskedastic consistent standard errors are in parenthesis. Significance level at which the null hypothesis is rejected: ***, $1 \%$; **, $5 \%$, and *, $10 \%$; Seigniorage, the dependent variable, was defined as the change in reserve money (IFS, line 14a) as a percentage of government revenues (IFS line 81); Models estimated with a constant and 3 decade dummies (1970s, 1980s, and 1990s). Their estimated coefficients are not shown in order to economize space.

in columns 3 and 4 . Since a pooled OLS, without fixed effects, would only have an adjusted $R^{2}$ of .07 , roughly .15 of the variation in seigniorage is not explained by independent variables listed. This also means that more work needs to be done in this topic in order to improve the explanatory power of our models.

The results of robustness tests based on the model of column 3 are shown in Table 3. Those reported in column 1 indicate that higher economic freedom is associated with lower reliance on seigniorage. A higher Index of Economic Freedom ${ }^{29}$ is associated with smaller governments, stronger legal structure and security of property rights, access to sound money, greater freedom

\footnotetext{
${ }^{29}$ Gwartney and Lawson's (2002) data on the Index of Economic Freedom starts in 1970 and has a 5-year frequency. In order to avoid missing values, straight line interpolation was used to generate annual data. Since Access to Sound Money is affected by seigniorage, we avoided eventual endogeneity problems by using a transformed index that excludes that area (Area III).
}

to exchange with foreigners, and more flexible regulations of credit, labor, and business. Since these are characteristics of more advanced economies with lesser need of seigniorage financing, the negative coefficient found conforms to our expectations. Revolutionary wars in the country and civil/ethnic conflicts in Border States (columns 2 and 3, respectively) lead to higher reliance on seigniorage. This result is intuitive, since these occurrences are associated with larger military spending, which may be at least partially seigniorage-financed. The model of column 4 indicates that fixed exchange rates ${ }^{30}$

\footnotetext{
${ }^{30}$ The result reported in column 7 is for the 5-way classification system of de facto exchange rate regimes of Levy-Yeyati and Sturzenegger (2003). Results are the same when their 3-way classification system is used instead. Since their data starts only in 1974, the inclusion of this variable originates a large number of missing values. That is why it was not included in the models of the previous columns. When included, it is always statistically significant, with a negative sign.
} 
lead to lower seigniorage levels. A possible explanation is that fixed exchange rates constrain monetary policy to the defense of the fixed parity and, thus, make the collection of seigniorage revenues harder. The results of column 5 confirm Click's (1998) result that seigniorage will be higher when the international creditworthiness of the country is lower. That is, when external borrowing is less available (or costlier), the government has to rely more heavily on seigniorage revenues. Finally, the last two columns test the effects of financial depth, which Woo (2003) found to be positively related with fiscal deficits. Two proxies taken from the database of financial development and structure of Beck et al. (2000) are used: the ratio of deposit money bank assets to central bank assets, and liquid liabilities as a percentage of GDP. Although both have the expected negative sign, indicating that countries with more developed financial markets are more capable of financing higher deficits without resorting to seigniorage, only the first of these variables is statistically significant. ${ }^{31}$

Despite all the tests implemented, which involved regressing seigniorage on a vast array of potential determinants, robustness may still be a concern. As the empirical economic growth literature has shown (see Durlauf et al., 1995, and Sala-i-Martin et al., 2004) the parameter estimates obtained in growth regressions are often sensitive to the inclusion of other conditional variables. Unfortunately, to our knowledge, there are no studies of the robust determinants of seigniorage that can be used to guide the decision of which variables to

\footnotetext{
$\overline{31}$ A series of additional robustness tests, whose results are not shown here, were also performed. First, the Freedom House ratings of Political Rights and Civil Liberties were used instead of the Polity Scale. None was statistically significant. The same result was obtained when using indicators of Executive Constraints (CNTS) and of Checks and Balances (DPI). Second, indicators of Ideological Polarization (DPI), Ideological Orientation (DPI) and Religious Homogeneity (SFTF) were added to the reference model, but were not statistically significant. Third, we also found that trading partners GDP growth (GDN), external debt (WDI), domestic debt (IFS), de jure central bank independence (CW), U.S. Treasury Bill rates (IFS), real effective exchange rates (WDI), current account balance (IFS), government revenues as a percentage of GDP (IFS), and dollarization ratios (share of dollar deposits) do not affect seigniorage in a statistically significant way. All results not shown in the paper are available from the authors upon request. Although the indicator of Ideological Polarization taken from the DPI was not statistically significant, we should not interpret this result as a rejection of the model of Cukierman et al. (1992) in which greater ideological polarization leads to higher seigniorage. Since this indicator only takes the values of 0,1 or 2 , it does not satisfactorily represent the wide differences in ideological polarization among countries. These may be better proxied by the indicators of social polarization used in this paper.
}

include in our estimations. ${ }^{32}$ Nevertheless, considering the persistence of our main results across a vast array of alternative specifications, it might be safe to argue that they are robust.

\subsection{Circumstances under which the effects of political instability on seigniorage are stronger}

Although our results regarding the relationship between political instability and seigniorage are clear, it is possible that they are stronger in some circumstances or in countries with specific characteristics. Aisen and Veiga (2006) found that political instability affect inflation levels especially in high-inflation and developing countries, whereas that relationship was practically non-existent in low inflation and industrialized countries. In order to check if the same happens with seigniorage, we performed estimations based in the model of column 3 of Table 2 in which Cabinet Changes was interacted with dummy variables accounting for annual inflation rates above and below 50\% and for developing and industrial countries. Results, illustrated in Fig. 1, ${ }^{33}$ are consistent with those of Aisen and Veiga (2006). That is, greater political instability, expressed in a higher number of cabinet changes, leads to higher seigniorage levels only in high-inflation and developing countries.

According to Woo $(2003,2005)$, social polarization, which can be proxied by income inequality and ethnic or religious heterogeneity/fractionalization, and the quality of institutions are important determinants of budget deficits. In highly polarized societies, the high heterogeneity of preferences may translate to political parties and interest groups lobbying for different types and amounts of government spending. Then, high polarization of interests may lead to higher seigniorage, in the presence of political instability. ${ }^{34}$ The quality of institutions is also very important because more stringent and transparent budgetary procedures, independence of the central bank, and greater parliamentary influence in the budgetary process can reduce the government's ability to increase budget deficits and extract seigniorage revenues.

\footnotetext{
32 Implementing an analysis such as that of Sala-i-Martin et al. (2004) to determine the robust determinants of seigniorage is beyond the scope of this paper.

33 The coefficient obtained for Cabinet Changes (Pol.Instability) in column 3 of Table 2 is shown in the first bar of Fig. 1. The estimation results for the interactions of Cabinet Changes considered in Fig. 1 are reported in Appendix C.

${ }^{34}$ In the model of Cukierman et al. (1992), this high polarization of interests results in higher seigniorage.
} 


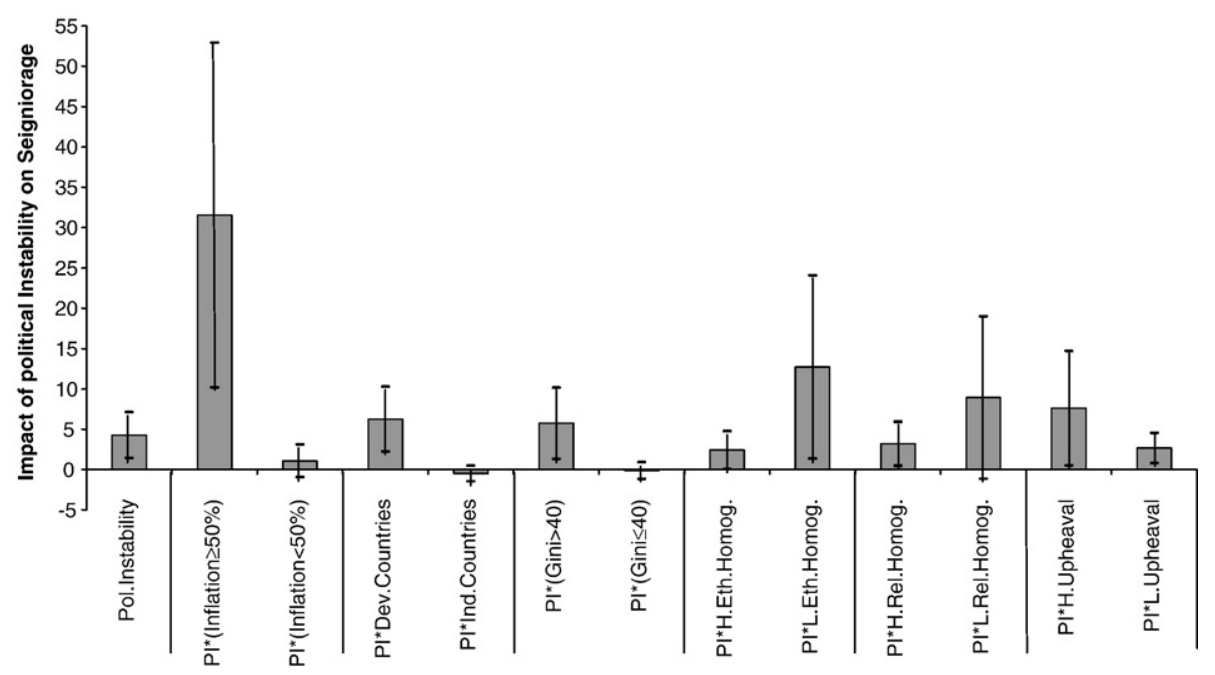

Fig. 1. Interactions of political instability. Notes: the grey bars show estimated coefficients of panel regressions: see column 3 of Table 2 for the coefficient of "Pol.Instability" (Cabinet changes), and in Appendix C, for the remaining coefficients (each pair, separated by vertical lines, corresponds to a separate estimation). 2-standard error bands are shown on top of the bars. In the horizontal axis, "H." stands for High, and "L." stands for Low. Seigniorage, the dependent variable, was defined as the change in reserve money (IFS, line 14a) as a percentage of government revenues (IFS line 81). The proxy used for political instability was Cabinet Changes (CNTS).

The hypothesis that the relationship between seigniorage and political instability is affected by social polarization is tested interacting Cabinet Changes with dummy variables for average Gini coefficients above and below $40,{ }^{35}$ for high and low ethnic homogeneity, ${ }^{36}$ and for high and low religious homogeneity. Results clearly support the hypothesis that political instability has stronger effects on seigniorage in countries with large social polarization (high income inequality and low ethnic or religious homogeneity). Finally, we test the hypothesis that political instability will have greater effects on seigniorage in countries that have traditionally been more unstable. Two dummy variables were created using the variable Upheaval from the $\mathrm{SFTF}^{37}$ which indicates the sum of the maximum magnitude of events in the prior 15 years, including revolutionary wars, ethnic wars, regime crises, and genocides/

\footnotetext{
35 The dummy Gini $>40$ takes the value of one for countries whose average Gini coefficient is above 40, and equals zero for the remaining countries $($ Gini $\leq 40)=1-($ Gini $>40)$.

36 The dummy Low Ethnic Homogeneity takes the value of one for countries whose respective index is equal to or lower than the 25 th percentile, and equals zero for the remaining countries (High Ethnic Homogeneity $=1-$ Low Ethnic Homogeneity). The same procedure was adopted for the religious homogeneity dummies.

${ }^{37}$ High Upheaval equals one when the value of Upheaval is above 3 , and equals zero otherwise (Low Upheaval=1-High Upheaval).
}

politicides. Although both dummies turned out as statistically significant, the magnitude of the coefficients implies that the number of cabinet changes in the previous year (our proxy for political instability) has greater impact on seigniorage in traditionally unstable countries. ${ }^{38}$

The hypothesis that institutions affect that relationship was tested interacting Cabinet Changes with dummy variables for high and low turnover rates of central bank presidents, ${ }^{39}$ for high and low economic freedom, ${ }^{40}$ and for Polity Scale below and above zero. The results, illustrated in the second and third bars of Fig. $2,{ }^{41}$ imply that greater political instability

\footnotetext{
${ }^{38}$ When Cabinet Changes is interacted with regional dummy variables, the positive effect of political instability on seigniorage is statistically significant only for Western Hemisphere (Latin American) and African countries. These results are not shown here, but are available upon request.

39 Cukierman et al. (1995) use this turnover rate as an indicator of de facto central bank independence. The dummy High Turnover takes the value of one when the turnover rate is above the sample median of 0.20 , and is zero otherwise (Low turnover $=1-$ High Turnover).

40 The dummy variable High Economic Freedom takes the value of one when the Index of Economic Freedom is greater than 5, and equals zero otherwise (Low Economic Freedom =1-High Economic Freedom). Again, we used a transformed index that excludes Area III (Access to Sound Money).

41 The estimation results for the interactions of Cabinet Changes considered in Fig. 2 are reported in Appendix D.
} 


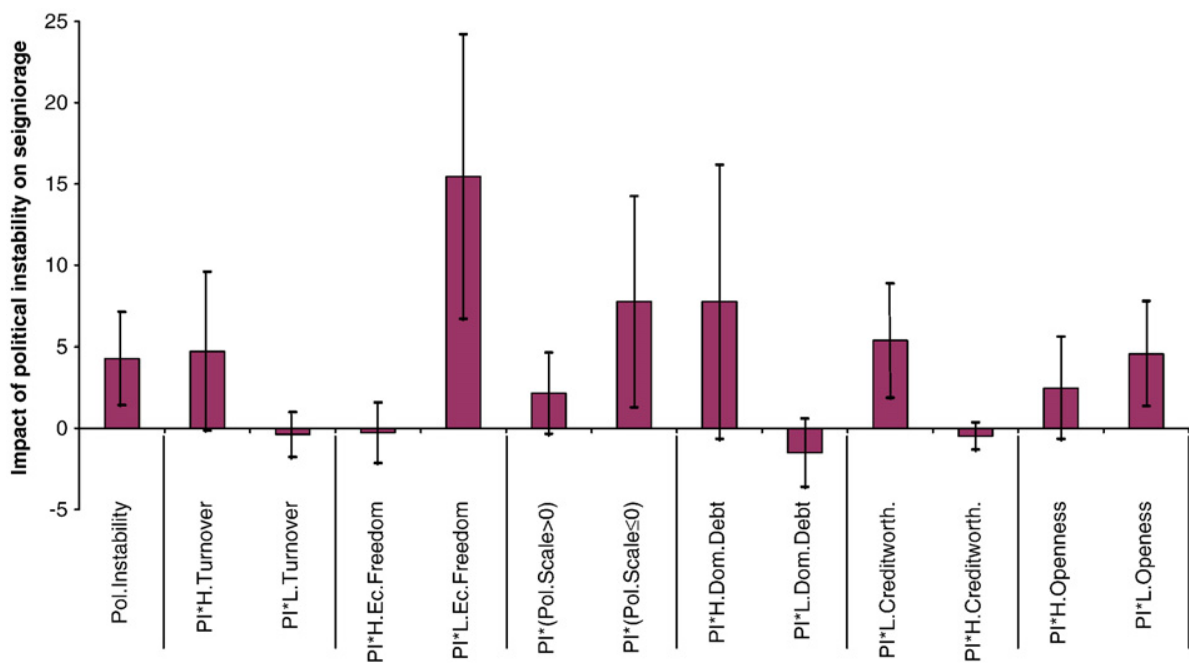

Fig. 2. More interactions of political instability. Notes: the grey bars show estimated coefficients of panel regressions: see column 3 of Table 2 for the coefficient of "Pol.Instability" (Cabinet changes), and in Appendix D, for the remaining coefficients (each pair, separated by vertical lines, corresponds to a separate estimation). 2-standard error bands are shown on top of the bars. In the horizontal axis, "H." stands for High, and "L." stands for Low. Seigniorage, the dependent variable, was defined as the change in reserve money (IFS, line 14a) as a percentage of government revenues (IFS line 81). The proxy used for political instability was Cabinet Changes (CNTS).

leads to higher seigniorage only when there is a high turnover rate of central bank presidents, that is, when the de facto independence of the central bank is low. When independence is high, seigniorage does not increase, as the government is no longer able to affect reserve money. ${ }^{42}$ Political instability also seems to affect seigniorage only in countries that have a low Index of Economic Freedom. This implies that the establishment of sounder and freer economic institutions is a way to reduce the impact of political instability on seigniorage. More democratic institutions also seem to matter, as the results indicate that political instability affects seigniorage less in democratic countries (Polity Scale $>0)$ than in countries under authoritarian regimes (Polity Scale $\leq$ ).

Click (1998) shows that when governments face greater constraints to issue domestic and/or external debt, they tend to resort more often to seigniorage revenues. We hypothesize that the effects of political instability on seigniorage levels also depend on the ratios of domestic

\footnotetext{
${ }^{42}$ It is worth noting that this result does not hold when the Cukierman et al. (1995) legal index of Central Bank Independence is used instead of the turnover rate of presidents (that proxies de facto independence). This may happen because what really matters for the conduct of monetary policy is the de facto independence and not what is written in the central bank law.
}

debt to GDP and on the countries' creditworthiness. That is, when greater political instability leads to higher deficits, governments resort more often to seigniorage revenues to finance them when domestic or foreign borrowing is more difficult (or costlier). The results provide empirical support for the above-referred hypothesis, as a greater number of Cabinet Changes is associated with higher seigniorage only in countries that have High Domestic Debt ${ }^{43}$ or Low Creditworthiness. ${ }^{44}$

Finally, we test the hypothesis that political instability will lead to greater seigniorage essentially in countries with lower trade openness ratios. Although we did not identify a direct relationship between openness and seigniorage in the estimations of Table 2, it is possible that openness to international trade affects the relationship between political instability and seigniorage. That is, in more open economies, the increase in government expenditures caused by political instability may be partially financed by higher taxes on

\footnotetext{
${ }^{43}$ High Domestic Debt (H.Dom.Debt) is a dummy variable that takes the value of one for the countries whose average ratio of domestic debt to GDP is above the countries' median ratio (13.28), and takes the value of zero otherwise (Low Domestic Debt $=1-$ High Domestic Debt).

${ }^{44}$ High Creditworthiness (H.Creditworth.) is a dummy variable that equals one for the countries whose average Euromoney's creditworthiness rating is above 60 (the 75th percentile of the country averages), and equals zero otherwise (Low Creditworthiness $=1-$ High Creditworthiness).
} 
Table 4

Results for indexes of political instability generated by Principal Components Analysis

\begin{tabular}{|c|c|c|c|c|c|c|c|c|c|}
\hline \multirow[t]{2}{*}{ Seigniorage } & \multicolumn{3}{|c|}{ Political Instability Index 1} & \multicolumn{3}{|c|}{ Political Instability Index 2} & \multicolumn{3}{|c|}{ Political Instability Index 3} \\
\hline & 1 & 2 & 3 & 4 & 5 & 6 & 7 & 8 & 9 \\
\hline Political Instability Index $(-1)$ & $\begin{array}{l}1.642 \\
(3.04)^{* * *}\end{array}$ & & & $\begin{array}{l}1.105 \\
(1.67)^{*}\end{array}$ & & & $\begin{array}{l}2.274 \\
(3.34)^{* * *}\end{array}$ & & \\
\hline [Political Instability Index * (inflation $\geq 50 \%)](-1)$ & & $\begin{array}{l}9.430 \\
(3.38)^{* * *}\end{array}$ & & & $\begin{array}{l}7.430 \\
(2.62)^{* * *}\end{array}$ & & & $\begin{array}{l}14.618 \\
(3.53)^{* * *}\end{array}$ & \\
\hline [Political Instability Index * (inflation $<50 \%)](-1)$ & & $\begin{array}{l}.056 \\
(.14)\end{array}$ & & & $\begin{array}{l}-.470 \\
(-.86)\end{array}$ & & & $\begin{array}{l}.438 \\
(1.23)\end{array}$ & \\
\hline [Political Instability Index *(developing countries)] $(-1)$ & & & $\begin{array}{l}2.117 \\
(3.05)^{* * *}\end{array}$ & & & $\begin{array}{l}1.211 \\
(1.63)^{*}\end{array}$ & & & $\begin{array}{l}3.978 \\
(3.50)^{* * *}\end{array}$ \\
\hline [Political Instability Index * (industrial countries)] $(-1)$ & & & $\begin{array}{l}-.061 \\
(-.17)\end{array}$ & & & $\begin{array}{l}.247 \\
(.35)\end{array}$ & & & $\begin{array}{l}-.237 \\
(-1.24)\end{array}$ \\
\hline Ethnic Homogeneity Index & $\begin{array}{l}-29.887 \\
(-3.21)^{* * *}\end{array}$ & $\begin{array}{l}-29.735 \\
(-3.29)^{* * *}\end{array}$ & $\begin{array}{l}-29.699 \\
(-3.17)^{* * *}\end{array}$ & $\begin{array}{l}-30.688 \\
(-3.30)^{* *}\end{array}$ & $\begin{array}{l}-30.818 \\
(-3.38)^{* * *}\end{array}$ & $\begin{array}{l}-30.614 \\
(-3.29)^{* * *}\end{array}$ & $\begin{array}{l}-29.388 \\
(-3.20)^{* * *}\end{array}$ & $\begin{array}{l}-27.612 \\
(-3.13)^{* * *}\end{array}$ & $\begin{array}{l}-28.425 \\
(-3.08)^{* * *}\end{array}$ \\
\hline Polity Scale & $\begin{array}{l}.353 \\
(1.69)^{*}\end{array}$ & $\begin{array}{l}.361 \\
(1.76)^{*}\end{array}$ & $\begin{array}{l}.350 \\
(1.68)^{*}\end{array}$ & $\begin{array}{l}.374 \\
(1.77)^{*}\end{array}$ & $\begin{array}{l}.382 \\
(1.80)^{*}\end{array}$ & $\begin{array}{l}.374 \\
(1.77)^{*}\end{array}$ & $\begin{array}{l}.318 \\
(1.52)\end{array}$ & $\begin{array}{l}.311 \\
(1.56)\end{array}$ & $\begin{array}{l}.286 \\
(1.38)\end{array}$ \\
\hline Urban population ( $\%$ of total) & $\begin{array}{l}-.483 \\
(-2.38)^{* *}\end{array}$ & $\begin{array}{l}-.435 \\
(-2.19)^{* *}\end{array}$ & $\begin{array}{l}-.468 \\
(-2.32)^{* *}\end{array}$ & $\begin{array}{l}-.519 \\
(-2.52)^{* *}\end{array}$ & $\begin{array}{l}-.512 \\
(-2.47)^{* *}\end{array}$ & $\begin{array}{l}-.517 \\
(-2.51)^{* *}\end{array}$ & $\begin{array}{l}-.466 \\
(-2.34)^{* *}\end{array}$ & $\begin{array}{l}-.363 \\
(-1.97)^{* *}\end{array}$ & $\begin{array}{l}-.419 \\
(-2.16)^{* *}\end{array}$ \\
\hline Real GDP per capita & $\begin{array}{l}-.002 \\
(-4.96)^{* * *}\end{array}$ & $\begin{array}{l}-.001 \\
(-4.86)^{* * *}\end{array}$ & $\begin{array}{l}-.002 \\
(-5.02)^{* * *}\end{array}$ & $\begin{array}{l}-.002 \\
(-5.01)^{* * *}\end{array}$ & $\begin{array}{l}-.002 \\
(-5.01)^{* * *}\end{array}$ & $\begin{array}{l}-.002 \\
(-5.04)^{* * *}\end{array}$ & $\begin{array}{l}-.002 \\
(-4.90) * * *\end{array}$ & $\begin{array}{l}-.001 \\
(-4.61)^{* * *}\end{array}$ & $\begin{array}{l}-.002 \\
(-5.01)^{* * *}\end{array}$ \\
\hline Growth of real GDP $(-1)$ & $\begin{array}{l}-.627 \\
(-3.75)^{* * *}\end{array}$ & $\begin{array}{l}-.467 \\
(-2.97)^{* * *}\end{array}$ & $\begin{array}{l}-.606 \\
(-3.67)^{* * *}\end{array}$ & $\begin{array}{l}-.658 \\
(-3.93)^{* * *}\end{array}$ & $\begin{array}{l}-.570 \\
(-3.52)^{* * *}\end{array}$ & $\begin{array}{l}-.656 \\
(-3.93)^{* * *}\end{array}$ & $\begin{array}{l}-.636 \\
(-3.79)^{* * *}\end{array}$ & $\begin{array}{l}-.437 \\
(-2.77)^{* * *}\end{array}$ & $\begin{array}{l}-.582 \\
(-3.55)^{* * *}\end{array}$ \\
\hline \# Observations & 2300 & 2300 & 2300 & 2306 & 2306 & 2306 & 2300 & 2300 & 2300 \\
\hline \# Countries & 108 & 108 & 108 & 108 & 108 & 108 & 108 & 108 & 108 \\
\hline Adjusted $R^{2}$ & .22 & .24 & .22 & .21 & .23 & .21 & .22 & .25 & .22 \\
\hline
\end{tabular}

Notes: Panel regressions controlling for country fixed effects. Seigniorage, the dependent variable, was defined as the change in reserve money (IFS, line 14a) as a percentage of government revenues (IFS line 81). Models estimated with a constant and 3 decade dummies (1970s, 1980s, and 1990s). Their estimated coefficients are not shown in order to economize space. T-statistics based on heteroskedastic consistent standard errors are in parenthesis. Significance level at which the null hypothesis is rejected: ***, 1\%; **, 5\%, and *, 10\% Variables used in the Principal Components Analysis to define each Political Instability Index (all variables were taken from the CNTS): P.I. Index 1: Assassinations, Cabinet Changes, Constitutional Changes, Coups, Executive Changes, Government Crises, and Revolutions; P.I. Index 2: Assassinations, Constitutional Changes, Coups, Government Crises, and Revolutions; P.I. Index 3: Cabinet Changes, Executive Changes, and Government Crises. 


\begin{tabular}{|c|c|c|c|c|c|c|c|c|}
\hline & \multicolumn{3}{|c|}{$\Delta$ Reserve money ( $\%$ GDP) } & \multicolumn{2}{|c|}{$\begin{array}{l}\text { Developing countries } \\
\Delta \text { Reserve money } \\
(\% \text { GovRev) }\end{array}$} & \multicolumn{3}{|c|}{$\begin{array}{l}\text { 3-Year MA of Cabinet Changes } \\
\Delta \text { Reserve money } \\
(\% \text { GovRev })\end{array}$} \\
\hline & 1 & 2 & 3 & 4 & 5 & 6 & 7 & 8 \\
\hline Cabinet Changes $(-1)$ & $\begin{array}{l}.202 \\
(2.00)^{* *}\end{array}$ & & & $\begin{array}{l}6.076 \\
(3.03)^{* * * *}\end{array}$ & & $\begin{array}{l}9.467 \\
(3.29)^{* * * *}\end{array}$ & & \\
\hline $\begin{array}{l}\text { [Cabinet changes* } \\
\quad(\text { inflation } \geq 50 \%)](-1)\end{array}$ & & $\begin{array}{l}2.019 \\
(3.41)^{* * *}\end{array}$ & & & $\begin{array}{l}52.191 \\
(2.99)^{* * *}\end{array}$ & & $\begin{array}{l}51.331 \\
(2.95)^{* * *}\end{array}$ & \\
\hline $\begin{array}{l}{[\text { Cabinet changes* }} \\
\quad(\text { inflation }<50 \%)](-1)\end{array}$ & & $\begin{array}{l}-.046 \\
(-.50)\end{array}$ & & & $\begin{array}{l}7.575 \\
(2.39)^{* *}\end{array}$ & & $\begin{array}{l}4.252 \\
(2.06)^{* *}\end{array}$ & \\
\hline $\begin{array}{l}\text { [Cabinet changes } * \\
\quad(\text { developing countries })](-1)\end{array}$ & & & $\begin{array}{l}.276 \\
(2.11)^{* *}\end{array}$ & & & & & $\begin{array}{l}15.067 \\
(3.61)^{* * *}\end{array}$ \\
\hline $\begin{array}{l}\text { [Cabinet changes } * \\
\quad(\text { industrial countries)] }(-1)\end{array}$ & & & $\begin{array}{l}-.029 \\
(-.37)\end{array}$ & & & & & $\begin{array}{l}-2.817 \\
(-3.77)^{* * *}\end{array}$ \\
\hline Ethnic Homogeneity Index & $\begin{array}{l}-3.982 \\
(-3.64)^{* * *}\end{array}$ & $\begin{array}{l}-3.621 \\
(-3.51)^{* * *}\end{array}$ & $\begin{array}{l}-3.987 \\
(-3.63)^{* * *}\end{array}$ & $\begin{array}{l}-25.868 \\
(-2.56)^{* *}\end{array}$ & $\begin{array}{l}-25.541 \\
(-2.39)^{* *}\end{array}$ & $\begin{array}{l}-26.390 \\
(-2.81)^{* * *}\end{array}$ & $\begin{array}{l}-24.714 \\
(-2.60)^{* * *}\end{array}$ & $\begin{array}{l}-25.903 \\
(-2.70)^{* * *}\end{array}$ \\
\hline Polity Scale & $\begin{array}{l}.032 \\
(1.77)^{*}\end{array}$ & $\begin{array}{l}.037 \\
(2.17)^{* *}\end{array}$ & $\begin{array}{l}.032 \\
(1.75)^{*}\end{array}$ & $\begin{array}{l}.450 \\
(1.88)^{*}\end{array}$ & $\begin{array}{l}.507 \\
(1.92)^{*}\end{array}$ & $\begin{array}{l}.308 \\
(1.50)\end{array}$ & $\begin{array}{l}.364 \\
(1.62)\end{array}$ & $\begin{array}{l}.284 \\
(1.40)\end{array}$ \\
\hline Urban population ( $\%$ of total) & $\begin{array}{l}-.15 \\
(-1.11)\end{array}$ & $\begin{array}{l}-.015 \\
(-1.11)\end{array}$ & $\begin{array}{l}-.015 \\
(-1.13)\end{array}$ & $\begin{array}{l}-.548 \\
(-2.10)^{* *}\end{array}$ & $\begin{array}{l}-.653 \\
(-2.41)^{* *}\end{array}$ & $\begin{array}{l}-.486 \\
(-2.53)^{* *}\end{array}$ & $\begin{array}{l}-.546 \\
(-2.60)^{* * *}\end{array}$ & $\begin{array}{l}-.472 \\
(-2.51)^{* *}\end{array}$ \\
\hline Real GDP per capita & $\begin{array}{l}-.0002 \\
(-5.85)^{* * *}\end{array}$ & $\begin{array}{l}-.0001 \\
(-5.48)^{* * *}\end{array}$ & $\begin{array}{l}-.0002 \\
(-5.81)^{* * *}\end{array}$ & $\begin{array}{l}-.002 \\
(-4.64)^{* * *}\end{array}$ & $\begin{array}{l}-.001 \\
(-2.43)^{* *}\end{array}$ & $\begin{array}{l}-.002 \\
(-5.09) * * *\end{array}$ & $\begin{array}{l}-.001 \\
(-3.75)^{* * *}\end{array}$ & $\begin{array}{l}-.002 \\
(-5.10)^{* * *}\end{array}$ \\
\hline Growth of real GDP $(-1)$ & $\begin{array}{l}-.043 \\
(-3.68)^{* * *}\end{array}$ & $\begin{array}{l}-.037 \\
(-3.07)^{* * *}\end{array}$ & $\begin{array}{l}-.043 \\
(-3.62)^{* * *}\end{array}$ & $\begin{array}{l}-.713 \\
(-3.69)^{* * *}\end{array}$ & $\begin{array}{l}-.532 \\
(-3.17)^{* * *}\end{array}$ & $\begin{array}{l}-.655 \\
(-3.86)^{* * *}\end{array}$ & $\begin{array}{l}-.450 \\
(-3.01)^{* * *}\end{array}$ & $\begin{array}{l}-.629 \\
(-3.77)^{* * *}\end{array}$ \\
\hline \# Observations & 3040 & 2908 & 3040 & 1674 & 1547 & 2282 & 2179 & 2282 \\
\hline \# Countries & 122 & 122 & 122 & 89 & 88 & 108 & 107 & 108 \\
\hline Adjusted $R^{2}$ & .24 & .27 & .25 & .19 & .24 & .22 & .27 & .23 \\
\hline
\end{tabular}

Notes: Panel regressions with fixed effects. $T$-statistics based on heteroskedastic consistent standard errors are in parenthesis. Significance level at which the null hypothesis is rejected: ***, 1\%; **, 5\%, and *, 10\%; Models estimated with a constant and 3 decade dummies (1970s, 1980s, and 1990s). Their estimated coefficients are not shown in order to economize space; The sample and the definition of seigniorage used (the dependent variable) are indicated in the first row.

trade, reducing the need to resort to seigniorage financing. Results shown in the last two bars of Fig. 2 are consistent with this hypothesis. ${ }^{45}$

\subsection{Sensitivity analysis}

Three alternative indexes of political instability were constructed by applying the Principal Components Analysis. The variables used to define each Political Instability Index were (all from the CNTS): ${ }^{46}$

\footnotetext{
45 It is worth noting that the interactions of Cabinet Changes with High Turnover and with High Domestic Debt are only statistically significant at the $10 \%$ level.

46 This technique for data reduction describes linear combinations of the variables that contain most of the information. It analyses the correlation matrix and the variables are standardized to have mean zero and standard deviation of 1 at the outset. Then, for each of the three groups of variables, the first component identified, the linear combination with greater explanatory power, was used as the political instability index.
}

o P.I. Index 1: Assassinations, Cabinet Changes, Constitutional Changes, Coups, Executive Changes, Government Crises, and Revolutions;

o P.I. Index 2: Assassinations, Constitutional Changes, Coups, Government Crises, and Revolutions (same as in Woo, 2003);

o P.I. Index 3: Cabinet Changes, Executive Changes, and Government Crises.

Table 4 reports the results of estimations using these alternative indexes. They are very similar to those obtained for Cabinet Changes, reported in Table 2 and Appendix C. Thus, our results are not sensitive to the choice of the proxy for political instability. That is, for all variables used, political instability is positively related to seigniorage.

Columns 1 to 3 of Table 5 report results obtained for an alternative definition of seigniorage: Change in Reserve Money as a percentage of GDP. In the models of columns 4 and 5 the sample contains only developing countries, and seigniorage is defined as in the previous 
tables. Finally, in the models of columns 6 to 8, a threeyear moving average of Cabinet Changes was used instead of its annual values, in order to better capture eventual persistent situations of political instability. In all cases, results are similar to those obtained in Tables 2 and Appendix $\mathrm{C}$, meaning that our conclusions regarding the effects of political, institutional and economic variables on seigniorage levels remain practically the same.

Results for alternative data frequencies are shown in Table 6. In columns 1, 3 and 5 the reference model was estimated for a cross-section of 108 countries and for panels of 10-year and 5-year averages. Results are still supportive of the hypothesis that political instability leads to greater seigniorage. Although the Ethnic Homogeneity Index is not statistically significant in the cross-section (column 1), the results for the panel estimations provide evidence in favor of the view that social polarization leads to seigniorage. The Index of Economic Freedom was added in columns 2, 4 and 6. As happened in column 1 of Table 3 , this variable is highly statistically significant, with a negative sign, reinforcing the conclusion that greater economic freedom is associated with lower reliance on seigniorage revenues.

It is possible that outliers associated with highinflation and high-seigniorage episodes affect the results of our regressions. This possibility is accounted for, using annual data, in columns 1 to 4 of Table 7 . In column 1, all observations for which annual inflation was above $1000 \%$ were excluded. Then, in column 2, we only included the observations for which seigniorage (as a percentage of government revenues) was smaller or equal to its mean plus two standard deviations $(\leq 156.76 \%)$. Results in both cases are very similar to those of the reference model. Then, we used two robust estimation procedures: least median of squares (LMS), in column 3; and, least absolute deviation (LAD), in column 4. In both cases, a greater number of cabinet changes is associated with higher seigniorage, but the Ethnic Homogeneity Index is not statistically significant when using LAD (column 4).

Finally, we estimated instrumental variables (IV) models in order to account for the possibility that someexplanatory variables are endogenous. Dealing with inflation, Aisen and Veiga (2006), used the system Generalized Method of Moments (GMM-SYS) estimator for dynamic panel data models. But, since lagged seigniorage is never statistically significant when included in our estimations, we do not have a dynamic panel. Thus, in columns 5 and 6 , we performed two-step feasible GMM and LIML (Limited

Table 6

Results for cross-section and period averages

\begin{tabular}{|c|c|c|c|c|c|c|}
\hline \multirow[t]{2}{*}{ Seigniorage } & \multicolumn{2}{|c|}{ Cross-section } & \multicolumn{2}{|c|}{10 -year periods } & \multicolumn{2}{|c|}{ 5-year periods } \\
\hline & 1 & 2 & 3 & 4 & 5 & 6 \\
\hline Cabinet Changes $(-1)$ & $\begin{array}{l}13.909 \\
(1.73)^{*}\end{array}$ & $\begin{array}{l}13.857 \\
(1.70)^{*}\end{array}$ & $\begin{array}{l}12.059 \\
(2.14)^{* *}\end{array}$ & $\begin{array}{l}16.132 \\
(1.98)^{* *}\end{array}$ & $\begin{array}{l}8.021 \\
(2.74)^{* * *}\end{array}$ & $\begin{array}{l}8.415 \\
(2.14)^{* *}\end{array}$ \\
\hline Ethnic Homogeneity Index & $\begin{array}{l}-2.800 \\
(-.52)\end{array}$ & $\begin{array}{l}-4.978 \\
(-.89)\end{array}$ & $\begin{array}{l}-8.937 \\
(-1.86)^{*}\end{array}$ & $\begin{array}{l}-14.330 \\
(-2.69)^{* * *}\end{array}$ & $\begin{array}{l}-6.887 \\
(-2.20)^{* *}\end{array}$ & $\begin{array}{l}-12.871 \\
(-3.24)^{* * *}\end{array}$ \\
\hline Polity Scale & $\begin{array}{l}-.539 \\
(-2.23)^{* *}\end{array}$ & $\begin{array}{l}-.423 \\
(-1.82)^{*}\end{array}$ & $\begin{array}{l}-.213 \\
(-1.23)\end{array}$ & $\begin{array}{l}-.243 \\
(-1.05)\end{array}$ & $\begin{array}{l}-.268 \\
(-2.00)^{* *}\end{array}$ & $\begin{array}{l}-.266 \\
(-1.42)\end{array}$ \\
\hline Urban population ( $\%$ of total) & $\begin{array}{l}.246 \\
(1.94)^{*}\end{array}$ & $\begin{array}{l}.171 \\
(1.43)\end{array}$ & $\begin{array}{l}266 \\
(3.13)^{* * *}\end{array}$ & $\begin{array}{l}.127) \\
(1.47\end{array}$ & $\begin{array}{l}.221 \\
(3.51)^{* * *}\end{array}$ & $\begin{array}{l}.094 \\
(1.36)\end{array}$ \\
\hline Real GDP per capita & $\begin{array}{l}-.001 \\
(-2.84)^{* * *}\end{array}$ & & $\begin{array}{l}-.001 \\
(-5.14)^{* * *}\end{array}$ & & $\begin{array}{l}-.001 \\
(-5.82)^{* * *}\end{array}$ & \\
\hline Growth of real GDP $(-1)$ & $\begin{array}{l}.142 \\
(.38)\end{array}$ & $\begin{array}{l}.471 \\
(.90)\end{array}$ & $\begin{array}{l}-1.300 \\
(-1.56)\end{array}$ & $\begin{array}{l}-1.567 \\
(-1.32)\end{array}$ & $\begin{array}{l}-1.134 \\
(-1.94)^{*}\end{array}$ & $\begin{array}{l}-1.047 \\
(-1.46)\end{array}$ \\
\hline Index of Economic Freedom & & $\begin{array}{l}-7.198 \\
(-2.63)^{* *}\end{array}$ & & $\begin{array}{l}-7.148 \\
(-4.27)^{* * *}\end{array}$ & & $\begin{array}{l}-6.656 \\
(-4.49)^{* * *}\end{array}$ \\
\hline \# Observations & 108 & 94 & 282 & 219 & 548 & 416 \\
\hline \# Countries & 108 & 94 & 96 & 87 & 108 & 94 \\
\hline Adjusted $R^{2}$ & .14 & .21 & .15 & .18 & .13 & .14 \\
\hline
\end{tabular}

Notes: Cross-section regressions estimated in columns 1 and 2 (including a constant); Panel regressions controlling for country fixed effects in columns 3 to 6 . Models estimated with a constant and period dummies. Their estimated coefficients are not shown in order to economize space; $T$ statistics based on heteroskedastic consistent standard errors are in parenthesis. Significance level at which the null hypothesis is rejected: ***, $1 \%$; $* *, 5 \%$, and *, 10\%; Seigniorage, the dependent variable, was defined as the change in reserve money (IFS, line 14a) as a percentage of government revenues (IFS line 81); In the cross-section regressions of columns 1 and 2, there are no lagged values of Cabinet Changes and Growth of Real GDP available. Thus, their average values for the entire sample period were used. In the other columns, the first lag is the average over the previous period. 
Table 7

Controlling for outliers and instrumental variables estimations

\begin{tabular}{|c|c|c|c|c|c|c|}
\hline \multirow[t]{2}{*}{ Seigniorage } & \multirow{2}{*}{$\frac{\text { Inflation } \leq 1000}{1}$} & \multirow{2}{*}{$\frac{\text { Seigniorage } \leq(\text { mean }+2 \mathrm{SD})}{2}$} & \multirow{2}{*}{$\frac{\mathrm{LMS}}{3}$} & \multirow{2}{*}{$\frac{\mathrm{LAD}}{4}$} & \multirow{2}{*}{$\frac{\text { IV GMM }}{5}$} & \multirow{2}{*}{$\frac{\text { IV LIML }}{6}$} \\
\hline & & & & & & \\
\hline \multirow[t]{2}{*}{ Cabinet Changes $(-1)$} & 3.436 & 1.284 & 1.903 & 1.148 & 41.135 & 39.256 \\
\hline & $(2.97)^{* * *}$ & $(2.23)^{* *}$ & $(7.04)^{* * *}$ & $(2.86)^{* * *}$ & $(1.91)^{*}$ & $(1.79)^{*}$ \\
\hline \multirow[t]{2}{*}{ Ethnic Homogeneity Index } & -25.853 & -17.043 & -5.340 & .821 & -12.812 & -11.837 \\
\hline & $(-2.76)^{* * *}$ & $(-2.40)^{* *}$ & $(-8.30)^{* * *}$ & $(.86)$ & $(-1.86)^{*}$ & $(-1.66)^{*}$ \\
\hline \multirow[t]{2}{*}{ Polity Scale } & .037 & .142 & .378 & -.167 & -.195 & -.199 \\
\hline & $(.19)$ & $(1.25)$ & $(13.9)^{* * *}$ & $(-4.13)^{* * *}$ & $(-.99)$ & $(-1.02)$ \\
\hline \multirow[t]{2}{*}{ Urban population ( $\%$ of total) } & -.115 & -.010 & -.029 & .081 & .297 & .313 \\
\hline & $(-.76)$ & $(-.12)$ & $(-3.02)^{* * *}$ & $(5.49)^{* * *}$ & $(2.32)^{* *}$ & $(2.38)^{* *}$ \\
\hline \multirow[t]{2}{*}{ Real GDP per capita } & -.001 & -.001 & -.001 & -.001 & -.001 & -.001 \\
\hline & $(-4.08)^{* * *}$ & $(-7.08)^{* * *}$ & $(-15.5)^{* * *}$ & $(-11.0)^{* * *}$ & $(-2.33)^{* *}$ & $(-2.38)^{* *}$ \\
\hline \multirow[t]{2}{*}{ Growth of real GDP $(-1)$} & -.293 & -.323 & .208 & -.068 & -.564 & -.531 \\
\hline & $(-2.62)^{* * *}$ & $(-3.58)^{* * *}$ & $(6.43)^{* * *}$ & $(-1.42)$ & $(-2.48)^{* *}$ & $(-2.27)^{* *}$ \\
\hline \# Observations & 2150 & 2293 & 2306 & 2306 & 2293 & 2293 \\
\hline \# Countries & 107 & 108 & 108 & 108 & 108 & 108 \\
\hline Adjusted $R^{2}$ & .18 & .25 & .02 & .05 & .13 & .10 \\
\hline
\end{tabular}

Notes: In columns 1 and 2, panel regressions controlling for country fixed effects were performed on the observations that complied with the conditions shown in the first row. Least Median of Squares estimation (LMS) was performed on the full sample in column 3, and Least Absolute Deviation (LAD) in column 4. Finally, instrumental variables estimations were performed in columns 5 and 6, using 2-step feasible Generalized Method of Moments (IV GMM) and Limited Information Maximum Likelihood (LIML), respectively; Seigniorage, the dependent variable, was defined as the change in reserve money (IFS, line 14a) as a percentage of government revenues (IFS line 81); All models estimated with a constant and 3 decade dummies (1970s, 1980s, and 1990s). Their estimated coefficients are not shown in order to economize space; $T$-statistics based on heteroskedastic consistent standard errors are in parenthesis. Significance level at which the null hypothesis is rejected: ***, 1\%; **, 5\%, and *, 10\%; The IV estimations of columns 5 and 6 were implemented using the command ivreg2 of Stata. Lagged values one and two periods of Cabinet Changes were used as instruments of that variable. Orthogonality tests do not reject the exogeneity of the other explanatory variables. The option cluster was used in order to account for intra-country correlation.

Information Maximum Likelihood), respectively, with instrumental variables. ${ }^{47}$ Results are consistent with the hypothesis that political instability and social polarization lead to greater reliance on seigniorage revenues. $^{48}$

\section{Conclusions}

The main purpose of this paper was to identify the major determinants of the cross-country and cross-time variability of seigniorage. Using a dataset

\footnotetext{
${ }^{47}$ These estimations were performed using the ivreg2 command of Stata. Lagged values one and two periods of Cabinet Changes were used as instruments for that variable. Using geographical dummies and other variables as additional instruments does not significantly change the results. Orthogonality tests do not reject the exogeneity of the other explanatory variables. The option cluster was used in order to account for intra-country correlation.

${ }^{48}$ One should note that the estimated coefficients for Cabinet Changes get very large. This may be due to weak instruments. In fact, when good instruments are not available, it may be preferable not to perform instrumental variables estimations.
}

covering about 100 countries, from 1960-1999, and applying standard panel data techniques, we found that greater political instability and social polarization lead to higher seigniorage. These results are consistent with the findings of previous studies such as Cukierman et al. (1992), Click (1998) and Woo (2003, 2005).

Our major contribution to the literature is that, in addition to the above-referred results, we succeeded to comprehensively determine the circumstances under which political instability has a greater impact on seigniorage, an important topic that received little attention in previous studies. Our results indicate that the effects of political instability on seigniorage are stronger in high-inflation, developing, sociallypolarized, and traditionally more unstable economies. Moreover, the same applies to countries with high turnover rates of central bank presidents (lower de facto central bank independence), with lower levels of economic freedom, that are less democratic, with higher domestic debt, with poorer creditworthiness ratings and with lower openness to international trade. 
Although the results concerning political instability and institutional variables are similar to those of Aisen and Veiga's (2006) study of inflation, there are several differences regarding other explanatory variables, which support our assertion that the determinants of inflation and seigniorage are not exactly the same and that it is necessary to conduct separate studies for these variables. In fact, seigniorage does not seem to be affected by changes in oil prices or US Treasury Bill rates (which affect inflation), but is determined by structural variables that condition the government's ability to raise taxes, such as the size of the agricultural sector, the urbanization ratio, and the level of GDP per capita, which do not seem to affect inflation.

The results of this study have policy implications that greatly contribute to the policy debate in highinflation (seigniorage) and politically unstable economies. Our results show that countries adopting policies targeting greater political stability, lower income inequality, and institutional strengthening, such as new laws governing central bank independence, limit the negative effect of political instability on seigniorage, improving their chances of successfully lowering their dependence on seigniorage revenues to finance their governments' deficits. After some time, they should benefit from lower inflation and, consequently, higher growth and economic prosperity.

\section{Appendix A. Seigniorage across countries}

\begin{tabular}{|c|c|c|c|}
\hline & Observations & Mean & SD \\
\hline \multicolumn{4}{|l|}{ Algeria } \\
\hline$\Delta \mathrm{RM} / \mathrm{GDP}$ & 31 & .033 & .018 \\
\hline \multicolumn{4}{|c|}{ Antigua and Barbuda } \\
\hline$\Delta \mathrm{RM} / \mathrm{GDP}$ & 22 & .013 & .035 \\
\hline \multicolumn{4}{|l|}{ Argentina } \\
\hline$\Delta \mathrm{RM} / \mathrm{GDP}$ & 38 & .060 & .078 \\
\hline$\Delta \mathrm{RM} / \mathrm{GR}$ & 18 & 1.203 & 1.287 \\
\hline \multicolumn{4}{|l|}{ Armenia } \\
\hline$\Delta \mathrm{RM} / \mathrm{GDP}$ & 5 & .026 & .026 \\
\hline \multicolumn{4}{|l|}{ Australia } \\
\hline$\Delta \mathrm{RM} / \mathrm{GDP}$ & 39 & .004 & .007 \\
\hline$\Delta \mathrm{RM} / \mathrm{GR}$ & 38 & .022 & .036 \\
\hline \multicolumn{4}{|l|}{ Austria } \\
\hline$\Delta \mathrm{RM} / \mathrm{GDP}$ & 38 & .005 & .002 \\
\hline$\Delta \mathrm{RM} / \mathrm{GR}$ & 37 & .020 & .013 \\
\hline \multicolumn{4}{|l|}{ Bahamas } \\
\hline$\Delta \mathrm{RM} / \mathrm{GDP}$ & 23 & .004 & .004 \\
\hline$\Delta \mathrm{RM} / \mathrm{GR}$ & 30 & .022 & .043 \\
\hline \multicolumn{4}{|l|}{ Bahrain } \\
\hline$\Delta \mathrm{RM} / \mathrm{GDP}$ & 24 & .008 & .022 \\
\hline
\end{tabular}

Appendix A (continued)

\begin{tabular}{|c|c|c|c|}
\hline & Observations & Mean & $\mathrm{SD}$ \\
\hline \multicolumn{4}{|l|}{ Bahrain } \\
\hline$\Delta \mathrm{RM} / \mathrm{GR}$ & 24 & .031 & .073 \\
\hline \multicolumn{4}{|l|}{ Bangladesh } \\
\hline$\Delta \mathrm{RM} / \mathrm{GDP}$ & 25 & .009 & .008 \\
\hline \multicolumn{4}{|l|}{ Barbados } \\
\hline$\Delta \mathrm{RM} / \mathrm{GDP}$ & 32 & .009 & .014 \\
\hline$\Delta \mathrm{RM} / \mathrm{GR}$ & 25 & .035 & .047 \\
\hline \multicolumn{4}{|l|}{ Belarus } \\
\hline$\Delta \mathrm{RM} / \mathrm{GDP}$ & 4 & .042 & .014 \\
\hline$\Delta \mathrm{RM} / \mathrm{GR}$ & 4 & .134 & .047 \\
\hline \multicolumn{4}{|l|}{ Belgium } \\
\hline$\Delta \mathrm{RM} / \mathrm{GDP}$ & 39 & .005 & .005 \\
\hline$\Delta \mathrm{RM} / \mathrm{GR}$ & 36 & .019 & .022 \\
\hline \multicolumn{4}{|l|}{ Belize } \\
\hline$\Delta \mathrm{RM} / \mathrm{GDP}$ & 22 & .010 & .012 \\
\hline$\Delta \mathrm{RM} / \mathrm{GR}$ & 19 & .041 & .052 \\
\hline \multicolumn{4}{|l|}{ Benin } \\
\hline$\Delta \mathrm{RM} / \mathrm{GDP}$ & 36 & .008 & .018 \\
\hline \multicolumn{4}{|l|}{ Bhutan } \\
\hline$\Delta \mathrm{RM} / \mathrm{GDP}$ & 15 & .035 & .053 \\
\hline$\Delta \mathrm{RM} / \mathrm{GR}$ & 13 & .184 & .294 \\
\hline \multicolumn{4}{|l|}{ Bolivia } \\
\hline$\Delta \mathrm{RM} / \mathrm{GDP}$ & 39 & .026 & .031 \\
\hline$\Delta \mathrm{RM} / \mathrm{GR}$ & 35 & .481 & 1.076 \\
\hline \multicolumn{4}{|l|}{ Botswana } \\
\hline$\Delta \mathrm{RM} / \mathrm{GDP}$ & 22 & .005 & .011 \\
\hline$\Delta \mathrm{RM} / \mathrm{GR}$ & 20 & .012 & .030 \\
\hline \multicolumn{4}{|l|}{ Brazil } \\
\hline$\Delta \mathrm{RM} / \mathrm{GDP}$ & 39 & .036 & .027 \\
\hline$\Delta \mathrm{RM} / \mathrm{GR}$ & 35 & .247 & .187 \\
\hline \multicolumn{4}{|l|}{ Bulgaria } \\
\hline$\Delta \mathrm{RM} / \mathrm{GDP}$ & 7 & .068 & .036 \\
\hline$\Delta \mathrm{RM} / \mathrm{GR}$ & 7 & .001 & .0001 \\
\hline \multicolumn{4}{|l|}{ Burkina Faso } \\
\hline$\Delta \mathrm{RM} / \mathrm{GDP}$ & 35 & .010 & .012 \\
\hline$\Delta \mathrm{RM} / \mathrm{GR}$ & 26 & .096 & .109 \\
\hline \multicolumn{4}{|l|}{ Burundi } \\
\hline$\Delta \mathrm{RM} / \mathrm{GDP}$ & 34 & .007 & .010 \\
\hline \multicolumn{4}{|l|}{ Cameroon } \\
\hline$\Delta \mathrm{RM} / \mathrm{GDP}$ & 35 & .005 & .008 \\
\hline$\Delta \mathrm{RM} / \mathrm{GR}$ & 20 & .021 & .058 \\
\hline \multicolumn{4}{|l|}{ Canada } \\
\hline$\Delta \mathrm{RM} / \mathrm{GDP}$ & 39 & .003 & .002 \\
\hline$\Delta \mathrm{RM} / \mathrm{GR}$ & 35 & .021 & .013 \\
\hline \multicolumn{4}{|c|}{ Central African Rep. } \\
\hline$\Delta \mathrm{RM} / \mathrm{GDP}$ & 37 & .011 & .018 \\
\hline Chad & & & \\
\hline$\Delta \mathrm{RM} / \mathrm{GDP}$ & 28 & .010 & .020 \\
\hline$\Delta \mathrm{RM} / \mathrm{GR}$ & 17 & .089 & .232 \\
\hline Chile & & & \\
\hline$\Delta \mathrm{RM} / \mathrm{GDP}$ & 39 & .069 & .077 \\
\hline$\Delta \mathrm{RM} / \mathrm{GR}$ & 38 & .283 & .281 \\
\hline China, P.R.: M & & & \\
\hline$\Delta \mathrm{RM} / \mathrm{GDP}$ & 13 & .063 & .026 \\
\hline$\Delta \mathrm{RM} / \mathrm{GR}$ & 13 & .474 & .250 \\
\hline China, P.R.: Hc & & & \\
\hline$\Delta \mathrm{RM} / \mathrm{GDP}$ & 8 & .007 & .005 \\
\hline Colombia & & & \\
\hline$\Delta \mathrm{RM} / \mathrm{GDP}$ & 37 & .019 & .009 \\
\hline
\end{tabular}




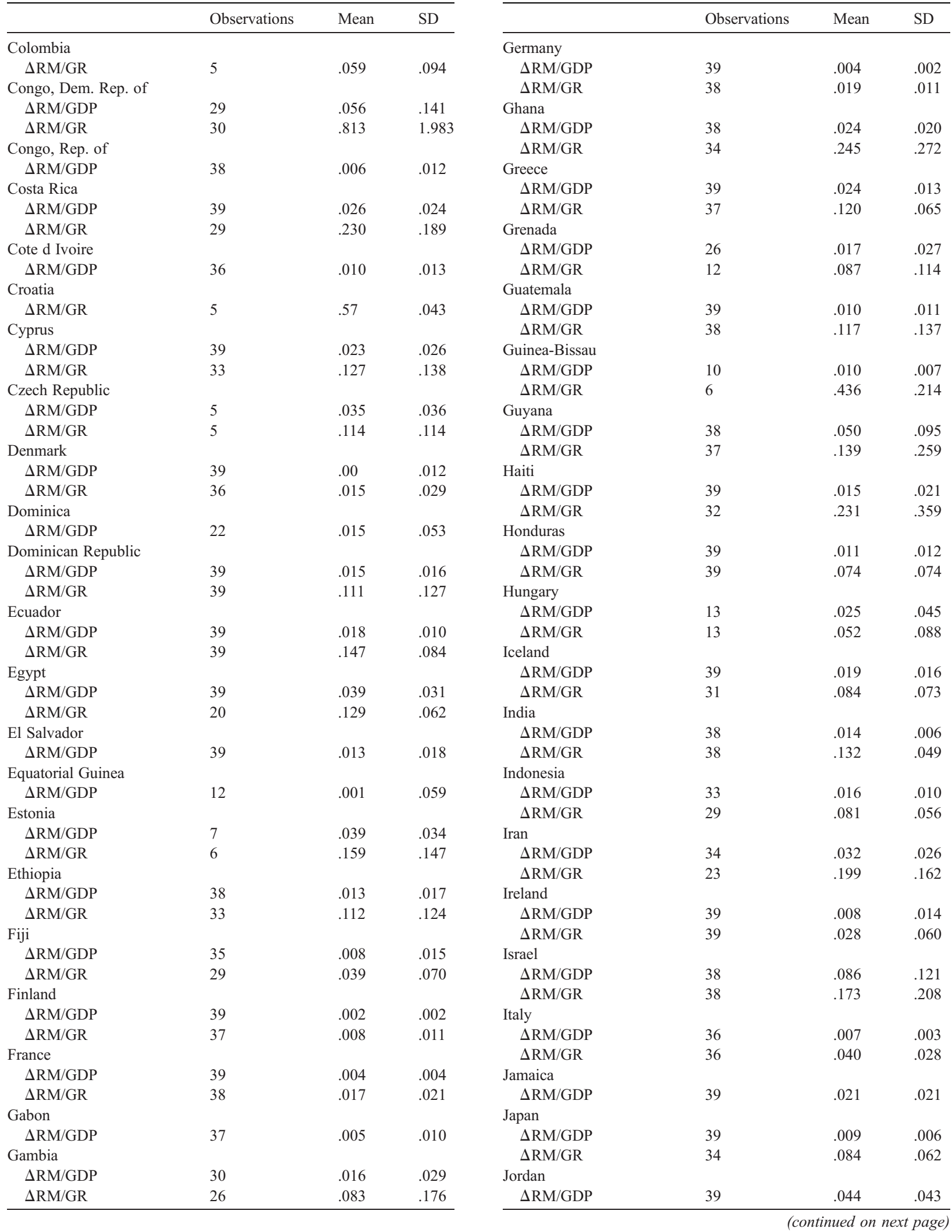


Appendix A (continued)

\begin{tabular}{|c|c|c|c|}
\hline & Observations & Mean & $\mathrm{SD}$ \\
\hline \multicolumn{4}{|l|}{ Jordan } \\
\hline$\Delta \mathrm{RM} / \mathrm{GR}$ & 38 & .225 & .203 \\
\hline \multicolumn{4}{|l|}{ Kazakhstan } \\
\hline$\Delta \mathrm{RM} / \mathrm{GR}$ & 5 & .115 & .161 \\
\hline \multicolumn{4}{|l|}{ Kenya } \\
\hline$\Delta \mathrm{RM} / \mathrm{GDP}$ & 32 & .014 & .014 \\
\hline$\Delta \mathrm{RM} / \mathrm{GR}$ & 28 & .061 & .059 \\
\hline \multicolumn{4}{|l|}{ Korea } \\
\hline$\Delta \mathrm{RM} / \mathrm{GDP}$ & 39 & .014 & .013 \\
\hline$\Delta \mathrm{RM} / \mathrm{GR}$ & 39 & .100 & .099 \\
\hline \multicolumn{4}{|l|}{ Kuwait } \\
\hline$\Delta \mathrm{RM} / \mathrm{GDP}$ & 35 & .002 & .019 \\
\hline$\Delta \mathrm{RM} / \mathrm{GR}$ & 31 & .005 & .044 \\
\hline \multicolumn{4}{|c|}{ Kyrgyz Republic } \\
\hline$\Delta \mathrm{RM} / \mathrm{GDP}$ & 3 & .015 & .007 \\
\hline$\Delta \mathrm{RM} / \mathrm{GR}$ & 3 & .089 & .045 \\
\hline \multicolumn{4}{|c|}{ Lao People's Dem. Rep } \\
\hline$\Delta \mathrm{RM} / \mathrm{GDP}$ & 9 & .014 & .009 \\
\hline \multicolumn{4}{|l|}{ Latvia } \\
\hline$\Delta \mathrm{RM} / \mathrm{GDP}$ & 5 & .016 & .012 \\
\hline$\Delta \mathrm{RM} / \mathrm{GR}$ & 4 & .048 & .037 \\
\hline \multicolumn{4}{|l|}{ Lebanon } \\
\hline$\Delta \mathrm{RM} / \mathrm{GR}$ & 4 & .406 & .224 \\
\hline \multicolumn{4}{|l|}{ Lesotho } \\
\hline$\Delta \mathrm{RM} / \mathrm{GDP}$ & 18 & .019 & .024 \\
\hline$\Delta \mathrm{RM} / \mathrm{GR}$ & 17 & .050 & .065 \\
\hline \multicolumn{4}{|l|}{ Libya } \\
\hline$\Delta \mathrm{RM} / \mathrm{GDP}$ & 33 & .027 & .033 \\
\hline \multicolumn{4}{|l|}{ Lithuania } \\
\hline$\Delta \mathrm{RM} / \mathrm{GDP}$ & 5 & .020 & .011 \\
\hline$\Delta \mathrm{RM} / \mathrm{GR}$ & 5 & .083 & .048 \\
\hline \multicolumn{4}{|l|}{ Luxembourg } \\
\hline$\Delta \mathrm{RM} / \mathrm{GDP}$ & 35 & .003 & .015 \\
\hline$\Delta \mathrm{RM} / \mathrm{GR}$ & 21 & .015 & .053 \\
\hline \multicolumn{4}{|l|}{ Madagascar } \\
\hline$\Delta \mathrm{RM} / \mathrm{GDP}$ & 36 & .011 & .013 \\
\hline$\Delta \mathrm{RM} / \mathrm{GR}$ & 21 & .112 & .153 \\
\hline \multicolumn{4}{|l|}{ Malawi } \\
\hline$\Delta \mathrm{RM} / \mathrm{GDP}$ & 33 & .014 & .023 \\
\hline \multicolumn{4}{|l|}{ Malaysia } \\
\hline$\Delta \mathrm{RM} / \mathrm{GDP}$ & 38 & .018 & .020 \\
\hline$\Delta \mathrm{RM} / \mathrm{GR}$ & 39 & .063 & .142 \\
\hline \multicolumn{4}{|l|}{ Maldives } \\
\hline$\Delta \mathrm{RM} / \mathrm{GR}$ & 20 & .248 & .350 \\
\hline \multicolumn{4}{|l|}{ Mali } \\
\hline$\Delta \mathrm{RM} / \mathrm{GDP}$ & 36 & .013 & .018 \\
\hline Malta & & & \\
\hline$\Delta \mathrm{RM} / \mathrm{GDP}$ & 38 & .059 & .091 \\
\hline$\Delta \mathrm{RM} / \mathrm{GR}$ & 36 & .157 & .268 \\
\hline Mauritania & & & \\
\hline$\Delta \mathrm{RM} / \mathrm{GDP}$ & 31 & .006 & .029 \\
\hline$\Delta \mathrm{RM} / \mathrm{GR}$ & 12 & .034 & .126 \\
\hline Mauritius & & & \\
\hline$\Delta \mathrm{RM} / \mathrm{GDP}$ & 39 & .015 & .028 \\
\hline$\Delta \mathrm{RM} / \mathrm{GR}$ & 32 & .090 & .148 \\
\hline Mexico & & & \\
\hline$\Delta \mathrm{RM} / \mathrm{GDP}$ & 39 & .022 & .024 \\
\hline$\Delta \mathrm{RM} / \mathrm{GR}$ & 27 & .235 & .220 \\
\hline
\end{tabular}

Appendix A (continued)

\begin{tabular}{|c|c|c|c|}
\hline & Observations & Mean & SD \\
\hline \multicolumn{4}{|l|}{ Moldova } \\
\hline$\Delta \mathrm{RM} / \mathrm{GDP}$ & 6 & .077 & .075 \\
\hline \multicolumn{4}{|l|}{ Mongolia } \\
\hline$\Delta \mathrm{RM} / \mathrm{GDP}$ & 6 & .039 & .022 \\
\hline$\Delta \mathrm{RM} / \mathrm{GR}$ & 5 & .197 & .118 \\
\hline \multicolumn{4}{|l|}{ Morocco } \\
\hline$\Delta \mathrm{RM} / \mathrm{GDP}$ & 39 & .015 & .009 \\
\hline$\Delta \mathrm{RM} / \mathrm{GR}$ & 31 & .071 & .042 \\
\hline \multicolumn{4}{|l|}{ Mozambique } \\
\hline$\Delta \mathrm{RM} / \mathrm{GDP}$ & 11 & .074 & .049 \\
\hline \multicolumn{4}{|l|}{ Myanmar } \\
\hline$\Delta \mathrm{RM} / \mathrm{GDP}$ & 38 & .028 & .048 \\
\hline$\Delta \mathrm{RM} / \mathrm{GR}$ & 33 & .332 & .516 \\
\hline \multicolumn{4}{|l|}{ Namibia } \\
\hline$\Delta \mathrm{RM} / \mathrm{GDP}$ & 7 & .006 & .005 \\
\hline$\Delta \mathrm{RM} / \mathrm{GR}$ & 3 & .016 & .023 \\
\hline \multicolumn{4}{|l|}{ Nepal } \\
\hline$\Delta \mathrm{RM} / \mathrm{GDP}$ & 39 & .014 & .008 \\
\hline$\Delta \mathrm{RM} / \mathrm{GR}$ & 37 & .223 & .149 \\
\hline \multicolumn{4}{|l|}{ Netherlands } \\
\hline$\Delta \mathrm{RM} / \mathrm{GDP}$ & 39 & .004 & .003 \\
\hline$\Delta \mathrm{RM} / \mathrm{GR}$ & 13 & .004 & .006 \\
\hline \multicolumn{4}{|c|}{ Netherlands Antilles } \\
\hline$\Delta \mathrm{RM} / \mathrm{GR}$ & 23 & .066 & .178 \\
\hline \multicolumn{4}{|l|}{ New Zealand } \\
\hline$\Delta \mathrm{RM} / \mathrm{GDP}$ & 39 & .001 & .008 \\
\hline$\Delta \mathrm{RM} / \mathrm{GR}$ & 37 & .006 & .029 \\
\hline \multicolumn{4}{|l|}{ Nicaragua } \\
\hline$\Delta \mathrm{RM} / \mathrm{GDP}$ & 38 & .058 & .091 \\
\hline$\Delta \mathrm{RM} / \mathrm{GR}$ & 39 & .255 & .370 \\
\hline \multicolumn{4}{|l|}{ Niger } \\
\hline$\Delta \mathrm{RM} / \mathrm{GDP}$ & 36 & .004 & .010 \\
\hline \multicolumn{4}{|l|}{ Nigeria } \\
\hline$\Delta \mathrm{RM} / \mathrm{GDP}$ & 35 & .014 & .016 \\
\hline$\Delta \mathrm{RM} / \mathrm{GR}$ & 34 & .136 & .168 \\
\hline \multicolumn{4}{|l|}{ Norway } \\
\hline$\Delta \mathrm{RM} / \mathrm{GDP}$ & 39 & .005 & .005 \\
\hline$\Delta \mathrm{RM} / \mathrm{GR}$ & 37 & .020 & .016 \\
\hline \multicolumn{4}{|l|}{ Oman } \\
\hline$\Delta \mathrm{RM} / \mathrm{GDP}$ & 28 & .009 & .013 \\
\hline$\Delta \mathrm{RM} / \mathrm{GR}$ & 27 & .024 & .033 \\
\hline \multicolumn{4}{|l|}{ Pakistan } \\
\hline$\Delta \mathrm{RM} / \mathrm{GDP}$ & 39 & .019 & .010 \\
\hline$\Delta \mathrm{RM} / \mathrm{GR}$ & 39 & .126 & .069 \\
\hline \multicolumn{4}{|c|}{ Papua New Guinea } \\
\hline$\Delta \mathrm{RM} / \mathrm{GDP}$ & 20 & .005 & .024 \\
\hline$\Delta \mathrm{RM} / \mathrm{GR}$ & 20 & .028 & .126 \\
\hline Paraguay & & & \\
\hline$\Delta \mathrm{RM} / \mathrm{GDP}$ & 39 & .018 & .010 \\
\hline$\Delta \mathrm{RM} / \mathrm{GR}$ & 34 & .177 & .094 \\
\hline Peru & & & \\
\hline$\Delta \mathrm{RM} / \mathrm{GDP}$ & 39 & .034 & .029 \\
\hline$\Delta \mathrm{RM} / \mathrm{GR}$ & 38 & .282 & .300 \\
\hline Philippines & & & \\
\hline$\Delta \mathrm{RM} / \mathrm{GDP}$ & 39 & .010 & .007 \\
\hline$\Delta \mathrm{RM} / \mathrm{GR}$ & 39 & .074 & .054 \\
\hline Poland & & & \\
\hline$\Delta \mathrm{RM} / \mathrm{GDP}$ & 18 & .050 & .059 \\
\hline$\Delta \mathrm{RM} / \mathrm{GR}$ & 9 & .067 & .088 \\
\hline
\end{tabular}




\begin{tabular}{|c|c|c|c|}
\hline & Observations & Mean & SD \\
\hline \multicolumn{4}{|l|}{ Portugal } \\
\hline$\Delta \mathrm{RM} / \mathrm{GDP}$ & 39 & .014 & .021 \\
\hline$\Delta \mathrm{RM} / \mathrm{GR}$ & 27 & .075 & .142 \\
\hline \multicolumn{4}{|l|}{ Qatar } \\
\hline$\Delta \mathrm{RM} / \mathrm{GDP}$ & 31 & .005 & .006 \\
\hline \multicolumn{4}{|l|}{ Romania } \\
\hline$\Delta \mathrm{RM} / \mathrm{GDP}$ & 19 & .031 & .035 \\
\hline$\Delta \mathrm{RM} / \mathrm{GR}$ & 23 & .076 & .084 \\
\hline \multicolumn{4}{|l|}{ Russia } \\
\hline$\Delta \mathrm{RM} / \mathrm{GR}$ & 4 & .185 & .077 \\
\hline \multicolumn{4}{|l|}{ Rwanda } \\
\hline$\Delta \mathrm{RM} / \mathrm{GDP}$ & 34 & .006 & .008 \\
\hline$\Delta \mathrm{RM} / \mathrm{GR}$ & 20 & .124 & .120 \\
\hline \multicolumn{4}{|l|}{ Saudi Arabia } \\
\hline$\Delta \mathrm{RM} / \mathrm{GDP}$ & 35 & .009 & .015 \\
\hline \multicolumn{4}{|l|}{ Senegal } \\
\hline$\Delta \mathrm{RM} / \mathrm{GDP}$ & 36 & .005 & .014 \\
\hline \multicolumn{4}{|l|}{ Seychelles } \\
\hline$\Delta \mathrm{RM} / \mathrm{GDP}$ & 27 & .014 & .037 \\
\hline$\Delta \mathrm{RM} / \mathrm{GR}$ & 21 & .040 & .098 \\
\hline \multicolumn{4}{|l|}{ Sierra Leone } \\
\hline$\Delta \mathrm{RM} / \mathrm{GDP}$ & 35 & .023 & .026 \\
\hline$\Delta \mathrm{RM} / \mathrm{GR}$ & 37 & .268 & .362 \\
\hline \multicolumn{4}{|l|}{ Singapore } \\
\hline$\Delta \mathrm{RM} / \mathrm{GDP}$ & 35 & .016 & .012 \\
\hline$\Delta \mathrm{RM} / \mathrm{GR}$ & 35 & .066 & .057 \\
\hline \multicolumn{4}{|c|}{ Slovak Republic } \\
\hline$\Delta \mathrm{RM} / \mathrm{GDP}$ & 5 & .020 & .022 \\
\hline \multicolumn{4}{|l|}{ Slovenia } \\
\hline$\Delta \mathrm{RM} / \mathrm{GDP}$ & 5 & .010 & .003 \\
\hline$\Delta \mathrm{RM} / \mathrm{GR}$ & 6 & .023 & .007 \\
\hline \multicolumn{4}{|l|}{ South Africa } \\
\hline$\Delta \mathrm{RM} / \mathrm{GDP}$ & 39 & .007 & .015 \\
\hline$\Delta \mathrm{RM} / \mathrm{GR}$ & 39 & .027 & .022 \\
\hline \multicolumn{4}{|l|}{ Spain } \\
\hline$\Delta \mathrm{RM} / \mathrm{GDP}$ & 39 & .011 & .004 \\
\hline$\Delta \mathrm{RM} / \mathrm{GR}$ & 37 & .078 & .040 \\
\hline \multicolumn{4}{|l|}{ Sri Lanka } \\
\hline$\Delta \mathrm{RM} / \mathrm{GDP}$ & 39 & .012 & .009 \\
\hline$\Delta \mathrm{RM} / \mathrm{GR}$ & 39 & .063 & .051 \\
\hline \multicolumn{4}{|c|}{ St. Kitts and Nevis } \\
\hline$\Delta \mathrm{RM} / \mathrm{GDP}$ & 18 & .016 & .036 \\
\hline$\Delta \mathrm{RM} / \mathrm{GR}$ & 10 & .057 & .051 \\
\hline \multicolumn{4}{|l|}{ St. Lucia } \\
\hline$\Delta \mathrm{RM} / \mathrm{GDP}$ & 22 & .012 & .014 \\
\hline \multicolumn{4}{|c|}{ St. Vincent \& Grens. } \\
\hline$\Delta \mathrm{RM} / \mathrm{GDP}$ & 22 & .015 & .034 \\
\hline$\Delta \mathrm{RM} / \mathrm{GR}$ & 20 & .049 & .121 \\
\hline Sudan & & & \\
\hline$\Delta \mathrm{RM} / \mathrm{GDP}$ & 38 & .035 & .031 \\
\hline Suriname & & & \\
\hline$\Delta \mathrm{RM} / \mathrm{GDP}$ & 31 & .069 & .074 \\
\hline Swaziland & & & \\
\hline$\Delta \mathrm{RM} / \mathrm{GDP}$ & 23 & .016 & .027 \\
\hline$\Delta \mathrm{RM} / \mathrm{GR}$ & 24 & .057 & .105 \\
\hline Sweden & & & \\
\hline$\Delta \mathrm{RM} / \mathrm{GDP}$ & 39 & .005 & .011 \\
\hline$\Delta \mathrm{RM} / \mathrm{GR}$ & 39 & .015 & .034 \\
\hline
\end{tabular}

\begin{tabular}{|c|c|c|c|}
\hline & Observations & Mean & $\mathrm{SD}$ \\
\hline \multicolumn{4}{|l|}{ Switzerland } \\
\hline$\Delta \mathrm{RM} / \mathrm{GDP}$ & 39 & .009 & .015 \\
\hline$\Delta \mathrm{RM} / \mathrm{GR}$ & 39 & .110 & .172 \\
\hline \multicolumn{4}{|c|}{ Syrian Arab Republic } \\
\hline$\Delta \mathrm{RM} / \mathrm{GDP}$ & 34 & .050 & .039 \\
\hline$\Delta \mathrm{RM} / \mathrm{GR}$ & 21 & .176 & .106 \\
\hline \multicolumn{4}{|l|}{ Tanzania } \\
\hline$\Delta \mathrm{RM} / \mathrm{GR}$ & 31 & .135 & .083 \\
\hline \multicolumn{4}{|l|}{ Thailand } \\
\hline$\Delta \mathrm{RM} / \mathrm{GDP}$ & 39 & .010 & .004 \\
\hline$\Delta \mathrm{RM} / \mathrm{GR}$ & 39 & .068 & .029 \\
\hline \multicolumn{4}{|l|}{ Togo } \\
\hline$\Delta \mathrm{RM} / \mathrm{GDP}$ & 35 & .011 & .033 \\
\hline \multicolumn{4}{|l|}{ Tonga } \\
\hline$\Delta \mathrm{RM} / \mathrm{GDP}$ & 12 & .012 & .074 \\
\hline \multicolumn{4}{|c|}{ Trinidad and Tobago } \\
\hline$\Delta \mathrm{RM} / \mathrm{GDP}$ & 38 & .008 & .016 \\
\hline$\Delta \mathrm{RM} / \mathrm{GR}$ & 30 & .023 & .054 \\
\hline \multicolumn{4}{|l|}{ Tunisia } \\
\hline$\Delta \mathrm{RM} / \mathrm{GDP}$ & 39 & .010 & .008 \\
\hline$\Delta \mathrm{RM} / \mathrm{GR}$ & 25 & .041 & .026 \\
\hline \multicolumn{4}{|l|}{ Turkey } \\
\hline$\Delta \mathrm{RM} / \mathrm{GDP}$ & 12 & .031 & .006 \\
\hline$\Delta \mathrm{RM} / \mathrm{GR}$ & 29 & .179 & .052 \\
\hline \multicolumn{4}{|l|}{ Uganda } \\
\hline$\Delta \mathrm{RM} / \mathrm{GDP}$ & 24 & .018 & .013 \\
\hline$\Delta \mathrm{RM} / \mathrm{GR}$ & 22 & .367 & .395 \\
\hline \multicolumn{4}{|l|}{ Ukraine } \\
\hline$\Delta \mathrm{RM} / \mathrm{GDP}$ & 5 & .074 & .072 \\
\hline \multicolumn{4}{|c|}{ United Arab Emirates } \\
\hline$\Delta \mathrm{RM} / \mathrm{GDP}$ & 23 & .009 & .013 \\
\hline$\Delta \mathrm{RM} / \mathrm{GR}$ & 16 & 4.215 & 8.255 \\
\hline \multicolumn{4}{|c|}{ United Kingdom } \\
\hline$\Delta \mathrm{RM} / \mathrm{GDP}$ & 39 & .004 & .005 \\
\hline$\Delta \mathrm{RM} / \mathrm{GR}$ & 36 & .013 & .015 \\
\hline \multicolumn{4}{|l|}{ United States } \\
\hline$\Delta \mathrm{RM} / \mathrm{GDP}$ & 39 & .003 & .001 \\
\hline$\Delta \mathrm{RM} / \mathrm{GR}$ & 36 & .021 & .009 \\
\hline \multicolumn{4}{|l|}{ Uruguay } \\
\hline$\Delta \mathrm{RM} / \mathrm{GDP}$ & 39 & .049 & .029 \\
\hline$\Delta \mathrm{RM} / \mathrm{GR}$ & 33 & .267 & .175 \\
\hline \multicolumn{4}{|l|}{ Vanuatu } \\
\hline$\Delta \mathrm{RM} / \mathrm{GDP}$ & 14 & .012 & .017 \\
\hline \multicolumn{4}{|l|}{ Venezuela } \\
\hline$\Delta \mathrm{RM} / \mathrm{GDP}$ & 39 & .015 & .016 \\
\hline$\Delta \mathrm{RM} / \mathrm{GR}$ & 38 & .066 & .071 \\
\hline \multicolumn{4}{|c|}{ Yemen, Republic of } \\
\hline$\Delta \mathrm{RM} / \mathrm{GDP}$ & 7 & .050 & .048 \\
\hline$\Delta \mathrm{RM} / \mathrm{GR}$ & 8 & .261 & .298 \\
\hline \multicolumn{4}{|l|}{ Zambia } \\
\hline$\Delta \mathrm{RM} / \mathrm{GDP}$ & 30 & .019 & .022 \\
\hline$\Delta \mathrm{RM} / \mathrm{GR}$ & 29 & .087 & .105 \\
\hline Zimbabwe & & & \\
\hline$\Delta \mathrm{RM} / \mathrm{GDP}$ & 21 & .010 & .007 \\
\hline$\Delta \mathrm{RM} / \mathrm{GR}$ & 18 & .042 & .026 \\
\hline
\end{tabular}

RM: reserve money (IMF-IFS-14a).

GDP: nominal GDP (IMF-IFS-99b).

GR: government revenues (IMF-IFS-81). 
Appendix B. Descriptive statistics

\begin{tabular}{|c|c|c|c|c|c|c|}
\hline Variables & Observations & Mean & SD & Min. & Max. & Source \\
\hline \multicolumn{7}{|l|}{ Dependent } \\
\hline$\Delta$ Reserve money ( $\%$ government revenues) & 3172 & 14.41 & 71.18 & -380.78 & 3108.74 & IFS-IFM \\
\hline$\Delta$ Reserve money (\%GDP) & 4376 & 1.87 & 3.62 & -29.4 & 65.53 & IFS-IFM \\
\hline \multicolumn{7}{|l|}{ Explanatory } \\
\hline Agriculture (\%GDP) & 4255 & 22.52 & 16.45 & .13 & 78.01 & WDI-WB \\
\hline Cabinet changes & 5667 & .44 & .6 & 0 & 5 & CNTS \\
\hline Change in terms of trade & 3978 & 220,801 & $1.5 \mathrm{E}+7$ & $-6.3 \mathrm{E}+7$ & $9.8 \mathrm{E}+8$ & WDI-WB \\
\hline Civil/ethnic conflicts in border states & 4957 & .87 & 1.14 & 0 & 6 & SFTF \\
\hline Creditworthiness & 1988 & 48.13 & 25.00 & 2.01 & 100 & Euromoney \\
\hline Deposit money bank assets/central bank assets & 4973 & .78 & .22 & -.11 & 1.34 & BDKL \\
\hline Domestic debt (\%GDP) & 1163 & 200.57 & 2588.54 & .12 & $52,345.17$ & IFS-IMF \\
\hline Ethnic Homogeneity Index & 4869 & .58 & .28 & 0 & 1 & SFTF \\
\hline Exchange rate regime & 3345 & 4.06 & 1.28 & 1 & 5 & LYS \\
\hline Executive changes & 5701 & .19 & .46 & 0 & 4 & CNTS \\
\hline Gini coefficient & 693 & 37.49 & 10.64 & 16.63 & 74.33 & DK \\
\hline Government revenues (\%GDP) & 2561 & 19.51 & 9.64 & 0 & 50.57 & WDI-WB \\
\hline Government crises & 5572 & .17 & .52 & 0 & 7 & CNTS \\
\hline Growth of real GDP & 4725 & 3.73 & 7.44 & -84.12 & 181.14 & WDI-WB \\
\hline Growth of real GDPpc & 4982 & 2.03 & 6.72 & -41.91 & 77.69 & PWT-6.1 \\
\hline Index of economic freedom & 2958 & 5.52 & 1.1 & 2.75 & 8.99 & GL \\
\hline Inflation (annual rate) & 4820 & 40.9 & 455.16 & -36.74 & $23,773.1$ & IFS-IFM \\
\hline Liquid liabilities (\%GDP) & 3572 & .39 & .28 & 0 & 2.22 & BDKL \\
\hline Polity Scale & 5344 & .08 & 7.62 & -10 & 10 & Polity IV \\
\hline Real GDP per capita & 5075 & 5936.76 & 6111.8 & 281.25 & $44,008.5$ & PWT-6.1 \\
\hline Religious homogeneity index & 4670 & .67 & .26 & 0 & 1 & SFTF \\
\hline Revolutionary war & 5431 & .09 & .29 & 0 & 1 & SFTF \\
\hline Trade (\%GDP) & 4815 & 70.06 & 46.37 & 0 & 439.59 & WDI-WB \\
\hline Turnover rate governors & 1990 & .24 & .2 & 0 & 1.08 & $\mathrm{CWN}$ \\
\hline Upheaval & 6000 & 5.63 & 11.88 & 0 & 61.5 & SFTF \\
\hline Urban population (\%total) & 6688 & 43.9 & 24.25 & 1.75 & 100 & WDI-WB \\
\hline
\end{tabular}

Notes: IFS-IMF: International Financial Statistics-International Monetary Fund; WDI-WB: World Development Indicators-World Bank; CNTS: Cross-National Time Series database; BDKL: Beck, Demirgüç-Kunt and Levine (2000); SFTF: State Failure Task Force database; LYS: Levy-Yeyati and Sturzenegger (2003); DK: Dollar and Kraay (2002); PWT-6.1: Penn World Tables (Mark 6.1); GL: Gwartney and Lawson (2002); CWN: based on Cukierman et al. (1995).

\section{Appendix C. Interactions of cabinet changes}

\begin{tabular}{|c|c|c|c|c|c|c|}
\hline Seigniorage & 1 & 2 & 3 & 4 & 5 & 6 \\
\hline $\begin{array}{l}\text { [Cabinet changes* } \\
\quad \quad \text { inflation } \geq 50 \%)](-1)\end{array}$ & $\begin{array}{l}31.560 \\
(2.95)^{* * *}\end{array}$ & & & & & \\
\hline $\begin{array}{l}\text { [Cabinet changes* } \\
\quad(\text { inflation }<50 \%)](-1)\end{array}$ & $\begin{array}{l}1.096 \\
(1.08)\end{array}$ & & & & & \\
\hline $\begin{array}{l}\text { [Cabinet changes* } \\
\quad \text { (developing countries)] }(-1)\end{array}$ & & $\begin{array}{l}6.270 \\
(3.12)^{* * *}\end{array}$ & & & & \\
\hline $\begin{array}{l}\text { [Cabinet changes* } \\
\quad \text { (industrial countries)] }(-1)\end{array}$ & & $\begin{array}{l}-.478 \\
(-.98)\end{array}$ & & & & \\
\hline$[$ Cabinet changes* $($ Gini $>40)](-1)$ & & & $\begin{array}{l}5.753 \\
(2.60)^{* * *}\end{array}$ & & & \\
\hline$[$ Cabinet changes* $($ Gini $\leq 40)](-1)$ & & & $\begin{array}{l}-.117 \\
(-.22)\end{array}$ & & & \\
\hline $\begin{array}{l}\text { [Cabinet changes* } \\
\quad \text { (low ethnic homogeneity)] }(-1)\end{array}$ & & & & $\begin{array}{l}12.714 \\
(2.24)^{* *}\end{array}$ & & \\
\hline $\begin{array}{l}\text { [Cabinet changes* } \\
\text { (high ethnic homogeneity)] }(-1)\end{array}$ & & & & $\begin{array}{l}2.423 \\
(2.06)^{* *}\end{array}$ & & \\
\hline
\end{tabular}


Appendix C (continued)

\begin{tabular}{|c|c|c|c|c|c|c|}
\hline Seigniorage & 1 & 2 & 3 & 4 & 5 & 6 \\
\hline $\begin{array}{l}\text { [Cabinet changes* } \\
\quad(\text { low religious homogeneity)] }(-1)\end{array}$ & & & & & $\begin{array}{l}8.940 \\
(1.78)^{*}\end{array}$ & \\
\hline $\begin{array}{l}\text { [Cabinet changes } * \\
\quad(\text { high religious homogeneity)] }(-1)\end{array}$ & & & & & $\begin{array}{l}3.203 \\
(2.34)^{* *}\end{array}$ & \\
\hline $\begin{array}{l}\text { [Cabinet changes * } \\
\quad(\text { high upheaval })](-1)\end{array}$ & & & & & & $\begin{array}{l}7.610 \\
(2.14)^{* *}\end{array}$ \\
\hline $\begin{array}{l}\text { [Cabinet changes* } \\
\quad(\text { low upheaval)] }(-1)\end{array}$ & & & & & & $\begin{array}{l}2.685 \\
(2.86)^{* * *}\end{array}$ \\
\hline Ethnic Homogeneity Index & $\begin{array}{l}-23.214 \\
(-2.59) * * *\end{array}$ & $\begin{array}{l}-24.193 \\
(-2.64) * * *\end{array}$ & $\begin{array}{l}-25.843 \\
(-2.90)^{* * *}\end{array}$ & $\begin{array}{l}-19.759 \\
(-2.01)^{* *}\end{array}$ & $\begin{array}{l}-22.867 \\
(-2.44)^{* *}\end{array}$ & $\begin{array}{l}-24.289 \\
(-2.69)^{* * *}\end{array}$ \\
\hline Polity Scale & $.336(1.64)$ & $.295(1.43)$ & $.120(.70)$ & $.261(1.28)$ & $.305(1.46)$ & $.322(1.57)$ \\
\hline Urban population ( $\%$ of total) & $\begin{array}{l}-.546 \\
(-2.44)^{* * *}\end{array}$ & $\begin{array}{l}-.482 \\
(-2.38)^{* *}\end{array}$ & $\begin{array}{l}-.093 \\
(-.87)\end{array}$ & $\begin{array}{l}-.460 \\
(-2.36)^{* *}\end{array}$ & $\begin{array}{l}-.497 \\
(-2.39)^{* *}\end{array}$ & $\begin{array}{l}-.460 \\
(-2.30)^{* *}\end{array}$ \\
\hline Real GDP per capita & $\begin{array}{l}-.001 \\
(-4.48)^{* * *}\end{array}$ & $\begin{array}{l}-.002 \\
(-5.32)^{* * *}\end{array}$ & $\begin{array}{l}-.001 \\
(-5.75)^{* * *}\end{array}$ & $\begin{array}{l}-.002 \\
(-5.31)^{* * *}\end{array}$ & $\begin{array}{l}-.002 \\
(-5.03) * * *\end{array}$ & $\begin{array}{l}-.002 \\
(-5.19)^{* * *}\end{array}$ \\
\hline Growth of real GDP $(-1)$ & $\begin{array}{l}-.521 \\
(-3.09) * * *\end{array}$ & $\begin{array}{l}-.640 \\
(-3.73)^{* * *}\end{array}$ & $\begin{array}{l}-.421 \\
(-3.47)^{* * *}\end{array}$ & $\begin{array}{l}-.644 \\
(-3.80)^{* * *}\end{array}$ & $\begin{array}{l}-.660 \\
(-3.72)^{* * *}\end{array}$ & $\begin{array}{l}-.647 \\
(-3.78)^{* * *}\end{array}$ \\
\hline \# Observations & 2247 & 2306 & 2250 & 2306 & 2284 & 2306 \\
\hline \# Countries & 107 & 108 & 105 & 108 & 107 & 108 \\
\hline Adjusted $R^{2}$ & .25 & .22 & .33 & .22 & .22 & .22 \\
\hline
\end{tabular}

Notes:Panel regressions controlling for country fixed effects;Seigniorage, the dependent variable, was defined as the change in reserve money (IFS, line 14a) as a percentage of government revenues (IFS line 81);Models estimated with a constant and 3 decade dummies (1970s, 1980s, and 1990s). Their estimated coefficients are not shown in order to economize space; $T$-statistics based on heteroskedastic consistent standard errors are in parenthesis. Significance level at which the null hypothesis is rejected: ${ }^{* * *}, 1 \% ;{ }^{* *}, 5 \%$, and ${ }^{*}, 10 \%$.

\section{Appendix D. More interactions of cabinet changes}

\begin{tabular}{|c|c|c|c|c|c|c|}
\hline Seigniorage & 1 & 2 & 3 & 4 & 5 & 6 \\
\hline $\begin{array}{l}\text { [Cabinet changes* } \\
\quad \text { (high turnover) }](-1)\end{array}$ & $\begin{array}{l}4.735 \\
(1.95)^{*}\end{array}$ & & & & & \\
\hline $\begin{array}{l}\text { [Cabinet changes * } \\
\quad(\text { low turnover)] }(-1)\end{array}$ & $\begin{array}{l}-.383 \\
(-.55)\end{array}$ & & & & & \\
\hline $\begin{array}{l}\text { [Cabinet changes* } \\
\quad(\text { low economic freedom })](-1)\end{array}$ & & $\begin{array}{l}15.460 \\
(3.53)^{* * *}\end{array}$ & & & & \\
\hline $\begin{array}{l}\text { [Cabinet changes* } \\
\quad(\text { high economic freedom })](-1)\end{array}$ & & $\begin{array}{l}-.274 \\
(-.29)\end{array}$ & & & & \\
\hline $\begin{array}{l}\text { [Cabinet changes* } \\
\quad(\text { Polity Scale } \leq 0)](-1)\end{array}$ & & & $\begin{array}{l}7.774 \\
(2.40)^{* *}\end{array}$ & & & \\
\hline $\begin{array}{l}\text { [Cabinet changes* } \\
\quad(\text { Polity Scale }>0)](-1)\end{array}$ & & & $\begin{array}{l}2.166 \\
(1.74)^{*}\end{array}$ & & & \\
\hline $\begin{array}{l}\text { [Cabinet changes* } \\
\quad(\text { high domestic debt)] }(-1)\end{array}$ & & & & $\begin{array}{l}7.766 \\
(1.85)^{*}\end{array}$ & & \\
\hline $\begin{array}{l}\text { [Cabinet changes* } \\
\quad(\text { low domestic debt)] }(-1)\end{array}$ & & & & $\begin{array}{l}-1.495 \\
(-1.43)\end{array}$ & & \\
\hline $\begin{array}{l}\text { [Cabinet changes* } \\
\quad \text { (low creditworthiness)] }(-1)\end{array}$ & & & & & $\begin{array}{l}5.382 \\
(3.08)^{* * *}\end{array}$ & \\
\hline $\begin{array}{l}\text { [Cabinet changes* } \\
\quad \text { (high creditworthiness)] }(-1)\end{array}$ & & & & & $\begin{array}{l}-.476 \\
(-1.13)\end{array}$ & \\
\hline $\begin{array}{l}\text { [Cabinet changes* } \\
\quad(\text { low openness] }(-1)\end{array}$ & & & & & & $\begin{array}{l}4.580 \\
(2.86)^{* * *}\end{array}$ \\
\hline $\begin{array}{l}\text { [Cabinet changes* } \\
\quad(\text { high openness)] }(-1)\end{array}$ & & & & & & $\begin{array}{l}2.481 \\
(1.59)\end{array}$ \\
\hline Ethnic Homogeneity Index & $\begin{array}{l}-32.133 \\
(-3.24)^{* * *}\end{array}$ & $\begin{array}{l}-29.650 \\
(-2.93)^{* * *}\end{array}$ & $\begin{array}{l}-24.808 \\
(-2.72)^{* * *}\end{array}$ & $\begin{array}{l}-18.016 \\
(-2.11)^{* *}\end{array}$ & $\begin{array}{l}-25.416 \\
(-2.85 * * *\end{array}$ & $\begin{array}{l}-24.931 \\
(-2.73)^{* * *}\end{array}$ \\
\hline Polity Scale & $\begin{array}{l}.205 \\
(1.05)\end{array}$ & $\begin{array}{l}.347 \\
(1.52)\end{array}$ & $\begin{array}{l}.487 \\
(2.09)^{* *}\end{array}$ & $\begin{array}{l}.294 \\
(1.49)\end{array}$ & $\begin{array}{l}.155 \\
(.88)\end{array}$ & $\begin{array}{l}.319 \\
(1.53)\end{array}$ \\
\hline
\end{tabular}




\begin{tabular}{lllllll}
\hline Seigniorage & 1 & 2 & 3 & 4 & 5 \\
\hline Urban population (\% of total) & -.065 & -.413 & -.471 & -.330 & -.095 \\
Real GDP per capita & $(-.32)$ & $(-1.92)^{*}$ & $(-2.36)^{* *}$ & $(-1.49)$ & $(-.89)$ & -.498 \\
& -.001 & -.002 & -.002 & -.002 & -.001 & $(-2.45)^{* *}$ \\
Growth of real GDP $(-1)$ & $(-3.35)^{* * *}$ & $(-4.56)^{* * *}$ & $(-5.36)^{* * *}$ & $(-5.24)^{* * *}$ & $(-6.03)^{* * *}$ & $(-5.26)^{* * *}$ \\
& -.348 & -.631 & -.615 & -.574 & -.421 & -.659 \\
\# Observations & $(-2.48)^{* *}$ & $(-3.38)^{* * *}$ & $(-3.71)^{* * *}$ & $(-2.97)^{* * *}$ & $(-3.45)^{* * *}$ & $(-3.78)^{* * *}$ \\
\# Countries & 1852 & 2082 & 2063 & 1788 & 2282 & 2297 \\
Adjusted $R^{2}$ & 102 & 105 & 102 & 104 & .108 & .32 \\
\hline
\end{tabular}

Notes:Panel regressions controlling for country fixed effects; Seigniorage, the dependent variable, was defined as the change in reserve money (IFS, line 14a) as a percentage of government revenues (IFS line 81); Models estimated with a constant and 3 decade dummies (1970s, 1980s, and 1990s). Their estimated coefficients are not shown in order to economize space; $T$-statistics based on heteroskedastic consistent standard errors are in parenthesis. Significance level at which the null hypothesis is rejected: ***, $1 \%$;**, $5 \%$, and $*, 10 \%$.

\section{References}

Aisen, A., Veiga, F.J., 2006. Does political instability lead to higher inflation? A panel data analysis. Journal of Money, Credit and Banking 38 (5), 1379-1389.

Aizenman, J., 1992. Competitive externalities and the optimal seigniorage. Journal of Money, Credit and Banking 24 (1), 61-71.

Albanesi, S., 2007. Inflation and inequality. Journal of Monetary Economics 54, 1088-1114.

Beck, T., Clarke, G., Groff, A., Keefer, P., Walsh, P., 2001. New Tools in comparative political economy: the database of political institutions. The World Bank Economic Review 15 (I), 165-176.

Beck, T., Demirgüç-Kunt, A., Levine, R., 2000. A new database on financial development and structure. World Bank Economic Review 14, 597-605.

Beetsma, R.M.W., Van Der Ploeg, F., 1996. Does inequality cause inflation? The political economy of inflation, taxation, and government debt. Public Choice 87, 143-162.

Bhattacharya, J., Bunzel, H., Haslag, J., 2005. The Non-monotonic relationship between seigniorage and inequality. Canadian Journal of Economics 38 (2), 500-519.

Buiter, W.H., 2007. Seigniorage. NBER Working Paper 12919.

Catão, L., Torrones, M., 2005. Fiscal deficits and inflation. Journal of Monetary Economics 52, 529-554.

Chelliah, R., Baas, H., Kelly, M., 1975. Tax ratios and tax effort in developing countries 1969-1971. IMF Staff Papers vol. 22, 187-205.

Click, R., 1998. Seigniorage in a cross-section of countries. Journal of Money, Credit and Banking 30 (2), 154-171.

Click, R., 2000. Seigniorage and conventional taxation with multiple exogenous shocks. Journal of Economic Dynamics \& Control 24, 1447-1479.

Cukierman, A., Edwards, S., Tabellini, G., 1992. Seigniorage and political instability. American Economic Review 82 (3), 537-555.
Cukierman, A., Webb, S., Neyapti, B., 1995. Measuring the independence of central banks and its effect on policy outcomes. The World Bank Economic Review 6 (3), 353-398.

Desai, R.M., Olofsgard, A., Yousef, T.M., 2005. Inflation and Inequality: does political structure matter? Economics Letters 87, 41-46.

Dollar, D., Kraay, A., 2002. Growth is good for the poor. Journal of Economic Growth 7, 195-225.

Durlauf, S., Johnson, P., Temple, J., 2005. Growth econometrics. In: Aghion, P., Durlauf, S. (Eds.), Handbook of Economic Growth. North-Holland, Amsterdam.

Easterly, W., Mauro, P., Schmidt-Hebbel, K., 1995. Money demand and seigniorage - maximizing inflation. Journal of Money, Credit and Banking 27 (2), 583-603.

Edwards, S., Tabellini, G., 1991. Explaining fiscal policy and inflation in developing countries. Journal of International Money and Finance 10, S16-S48.

Fischer, S., Sahay, R., Végh, C., 2002. Modern hyper- and high inflations. Journal of Economic Literature 40 (3), 837-880.

Gwartney, J., Lawson, R., 2002. Economic Freedom of the World 2002 Annual Report. Fraser Institute, Vancouver, B.C.

Levy-Yeyati, E., Sturzenegger, F., 2003. To float or to fix: evidence on the impact of exchange rate regimes on growth. American Economic Review 93 (4), 1173-1193.

Phelps, E., 1973. Inflation in the theory of public finance. Swedish Journal of Economics 75, 67-82.

Sala-i-Martin, X., Doppelhofer, G., Miller, R., 2004. Determinants of long-term growth: a Bayesian Averaging of Classical Estimates (BACE) approach. American Economic Review 94, 813-835.

Végh, C., 1989. Government Spending and inflationary finance: a public finance approach. IMF Staff Papers 36, 657-677.

Woo, J., 2003. Economic, political, and institutional determinants of public deficits. Journal of Public Economics 87, 387-426.

Woo, J., 2005. Social polarization, fiscal instability, and growth. European Economic Review 49, 1451-1477. 